\title{
Sheet intrusions and deformation of Piton des Neiges, and their implication for the volcano-tectonics of La Réunion
}

\author{
Marie Chaput ${ }^{\mathrm{a}, \mathrm{b}}$, Vincent Famin ${ }^{\mathrm{a}, *}$, Laurent Michon ${ }^{\mathrm{a}}$ \\ a Laboratoire GéoSciences Réunion, Université de La Réunion, Institut de Physique du Globe de Paris, Sorbonne Paris Cité, UMR 7154 CNRS, F-97744, Saint Denis, France \\ b Bureau d'études Stratagem974, 62 Boulevard du Chaudron, 97490 Sainte-Clotilde, La Réunion, France
}

\begin{abstract}
A B S T R A C T
To understand the volcano-tectonic history of Piton des Neiges (the dormant volcano of La Réunion), we measured in the field the orientation of sheeted intrusions and deformation structures, and interpreted the two datasets separately with a paleostress inversion. Results show that the multiple proposed rift zones may be simplified into three trends: (1) a $\mathrm{N} 30^{\circ} \mathrm{E}, 5 \mathrm{~km}$ wide linear rift zone running to the south of the edifice, active in the shield building ( $\geq 2.48-0.43 \mathrm{Ma}$ ) and terminal stages (190-22 ka); (2) a curved $\mathrm{N} 110$ to $\mathrm{N} 160^{\circ} \mathrm{E}$ rift zone, widening from $5 \mathrm{~km}$ to $10 \mathrm{~km}$ toward the NW flank, essentially active during the early emerged shield building ( $\geq 1.3 \mathrm{Ma}$ ); and (3) two sill zones, $\leq 1 \mathrm{~km}$ thick in total, in the most internal parts of the volcano, active in the shield building and terminal stages.

In parallel, deformation structures reveal that the tectonics of the edifice consisted in three end-member stress regimes sharing common stress axes: (1) NW-SE extension affecting in priority the south of the edifice near the $\mathrm{N} 30^{\circ} \mathrm{E}$ rift zone; (2) NNE-SSW extension on the northern half of the volcano near the $N 110-160^{\circ} \mathrm{E}$ rift zone; (3) compression occurring near the sill zones, with a NE-SW or NW-SE maximum principal stress. These three stress regimes are spatially correlated and mechanically compatible with the injection trends.

Combined together, our data show that the emerged Piton des Neiges underwent sector spreading delimited by perpendicular rift zones, as observed on Piton de la Fournaise (the active volcano of La Réunion). Analogue experiments attribute such sector spreading to brittle edifices built on a weaker substratum. We therefore conclude that La Réunion volcanoes are both brittle, as opposed to Hawaiian volcanoes or Mount Etna whose radial spreading is usually attributed to a ductile body within the edifices.
\end{abstract}

\section{Introduction}

Basaltic shield volcanoes may undergo important flank deformation during eruptive events, and sometimes even during quiescent periods. This is the case at Piton de la Fournaise volcano (La Réunion Island), for which a large creep of the eastern flank toward the sea occurred during the April 2007 eruption and persisted for one year afterwards (Clarke et al., 2013; Froger et al., 2015; Got et al., 2013; Tridon et al., 2016). Such flank deformation represents a potential hazard because it may generate earthquakes or even tsunamigenic flank failures. In Hawaii, for instance, the slip of the southern flank of Kilauea on a basal décollement is responsible for up to M7.2 earthquakes. On this edifice as well as on other volcanoes of the Canaries and La Réunion, onshore and offshore mass wasting deposits attest to the occurrence of large, catastrophic destabilizations that are the direct consequence of flank failure. Volcano flank deformation is dependent of many factors such as the geometry of the plumbing system, the shape and internal structure of the edifice, and its state of stress (e.g. Oehler et al., 2005; Tibaldi, 2015). Quantitatively assessing the contribution of each different factor and their interaction at depth is thus of prime importance for the understanding - and prediction - of flank deformation. In practice, however, the effect of each factor is extremely difficult to quantify, firstly because our knowledge of deep structures in active volcanoes is limited by the resolution of geophysical techniques, and secondly because the volcano-tectonic seismicity is often too subtle to allow an inversion of principal stresses in the edifice.

One way to improve our knowledge of the inner intrusive structure of basaltic shield volcanoes is to study inactive edifices exposed by erosion and to consider them as analogues of active volcanoes. On some of these eroded volcanoes, the problem of stress state determination may be also solved by a paleostress inversion of deformation microstructures. Piton des Neiges, the dormant volcano of La Réunion (Fig. 1), is a perfect example to conduct such a dual study of intrusions and deformation. The intense tropical erosion of this volcano provides

\footnotetext{
* Corresponding author.

E-mail address: vfamin@univ-reunion.fr (V. Famin).
} 

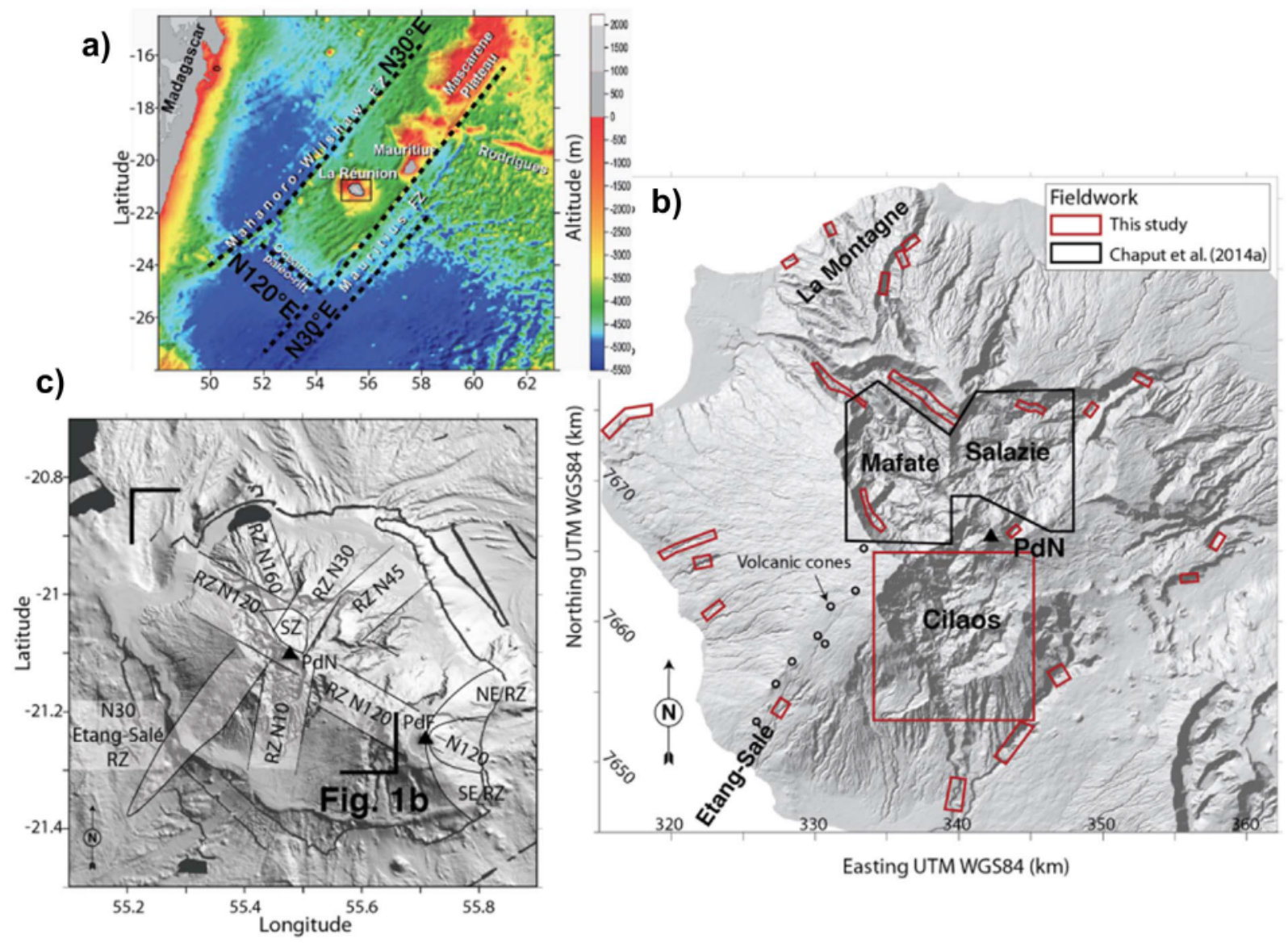

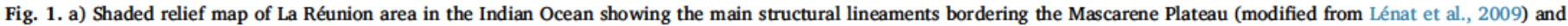

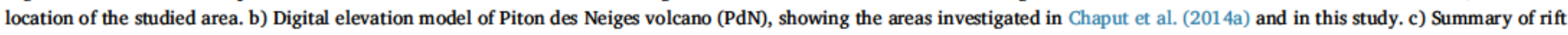

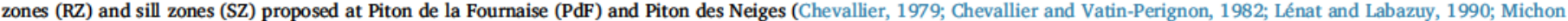
et al., 2007; Chaput et al., 2014a; Michon et al., 2015).

an exceptional access to its internal structure and plumbing system due to the three deep cirques (circular valleys) that formed around its summit. Piton des Neiges is also heavily deformed, and therefore offers an opportunity to study the relationships between the internal architecture, the magmatic activity, stresses and deformation of a basaltic volcano. Such work has already been undertaken in the cirques of Salazie and Mafate (Famin and Michon, 2010; Chaput et al., 2014a), but remains to be extended to the entire emerged edifice in order to provide a wider view of Piton des Neiges' volcano-tectonics.

In this paper, we describe the structure of Piton des Neiges from its outer flanks to its most internal parts, with particular emphasis on the cirque of Cilaos. We made a detailed investigation of the geometrical features of sheet intrusions and deformation structures that crosscut the geological formations in these parts of the edifice. An inversion procedure was applied to intrusion and deformation data to determine the stress state under which magma intrusions and deformation were generated. The work presented here provides an integrated description of the geometry of sheet intrusion swarms and the organization of stresses at the scale of the emerged edifice. This description is critical to explain how the intrusive system and stresses interact with each other to generate flank deformation at Piton des Neiges, an understanding that may be directly applicable to Piton de la Fournaise and other active basaltic shield volcanoes alike.

\section{Geological background}

La Réunion (Indian Ocean) is a $\sim 5$ Ma old intraplate shield volcanic island, built at $4000 \mathrm{~m}$ below sea level on a Paleocene sea floor. It lies on a bathymetric high, south of the Mascarene Plateau (Fig. 1a), bordered by a $\mathrm{N} 120^{\circ} \mathrm{E}$ paleoridge segment to the SW and by two $\mathrm{N} 30^{\circ} \mathrm{E}$ transform faults to the NW and SE (Fretzdorff et al., 1998; Bernard and Munschy, 2000). These main crustal structures are considered as inactive since $\sim 60 \mathrm{Ma}$ (Dyment, 1991).

La Réunion displays a subcircular shape, $200-240 \mathrm{~km}$ in diameter. Its submarine slopes are mostly composed of dismantling products, organized as four major bulges, north, east, south and west of the island (Labazuy, 1996; Oehler et al., 2008; Le Friant et al., 2011). On land, La Réunion is elliptical in shape, elongated along a $\mathrm{N} 120^{\circ} \mathrm{E}$ axis. The island is composed of two main volcanic centers, the inactive Piton des Neiges to the West, and the active Piton de la Fournaise, built since $\sim 530 \mathrm{ka}$ on the eastern flank of Piton des Neiges (Gillot et al., 1990). The shield building stage of emerged Piton des Neiges began before 2.2 Ma with the emission of basic magmas (mainly basalt and picrite) of the transitional series (McDougall, 1971; Kluska, 1997; Quidelleur et al., 2010). Shield building pertained until $430 \mathrm{ka}$. After a $\sim 90 \mathrm{ka}$ period of erosion, the volcano entered in a differentiated stage with the emission of hawaiite (mostly feldspar-rich) and mugearite from 350 to $190 \mathrm{ka}$, and then of benmoreite, trachyte or syenite until 22 ka (Gillot and Nativel, 1982; Deniel et al., 1992; Kluska, 1997). The emerged flanks of Piton des Neiges volcano are now made of a thick (several hundred meters) basic lava flow sequence emplaced during the shield building stage, and capped by alkalic differentiated lavas and ignimbrites. Large volumes of breccia are also observed, interpreted as debris avalanche deposits or as debris flows and slope breccia (Maillot, 1999; Bachèlery et al., 2003; Bret et al., 2003; Arnaud, 2005; Oehler et al., 2005, 2008; Lacquement and Nehlig, 2008; Famin and Michon, 2010). The lowermost rock unit 
of Piton des Neiges accessible to observation is a gabbro outcropping in the cirque of Salazie, and imaged by geophysics as a kilometer scale plutonic complex centered on the cirque of Salazie (e.g. Gailler and Lénat, 2012).

Piton des Neiges volcano is incised by three subcircular valleys: the cirque of Salazie to the north, the cirque of Mafate to the west, and the cirque of Cilaos to the south (Fig. 1b). These depressions have been alternatively interpreted as scars of large flank collapses (Bret et al., 2003; Oehler et al., 2004; Oehler et al., 2008), as sector grabens caused by gravitational spreading (Borgia et al., 2000; Oehler et al., 2005; Delcamp et al., 2008, 2012; Byme et al., 2013), as a consequence of plutonic complex subsidence (Gailler and Lénat, 2012) or else as purely regressive erosional structures (Haurie, 1987; Salvany et al., 2012).

The multiplicity of preferential magma injection trends proposed for Piton des Neiges illustrates the complexity of identifying rift zones for this volcano (Fig. 1c). The first major trend corresponds to a rift zone $\mathrm{N} 120-140^{\circ} \mathrm{E}$ in the cirque of Mafate and active mostly during the shield building stage of the edifice (Chevallier, 1979; Chevallier and VatinPerignon, 1982; Chaput et al., 2014a). The second injection trend, located on the southwestern flank of Piton des Neiges and oriented $\mathrm{N} 30^{\circ} \mathrm{E}$, corresponds to an alignment of late eruptive vents prolonged seaward by a narrow ridge (Fig. 1b-c; Lénat and Labazuy, 1990). Lavas on this offshore ridge have been dated at $2.48 \pm 0.05 \mathrm{Ma}$ (Smietana, 2011). The third proposed trend, oriented $N 160^{\circ} \mathrm{E}$, is found on the La Montagne Massif. Other minor trends oriented $\mathrm{N} 10^{\circ} \mathrm{E}, \mathrm{N} 45^{\circ} \mathrm{E}$, and $\mathrm{N} 55^{\circ} \mathrm{E}$, radial to the summit of the edifice have been proposed (Chevallier, 1979; Chevallier and Vatin-Perignon, 1982; Maillot, 1999), though their existence is still debated (Michon et al., 2007). Another important feature is the occurrence of low-dipping planar intrusions in the cirques, first reported by Chevallier (1979) and emphasized by Famin and Michon (2010) and Berthod et al. (2016). Chaput et al. (2014a) extensively described these low-dipping intrusions and showed that they are abundant in the cirque of Salazie but almost absent of the cirque of Mafate. Low-dipping intrusions are found crosscutting lithological units or following lithological contacts, in which case they are sills. They may occur as isolated intrusions, but also as thick piles of multiple sheets termed "sill zones" by Chaput et al. (2014a) by analogy with rift zones.

Previous studies showed that deformation in the cirques is essentially brittle, except in a sill zone within Salazie where a low-temperature ductile simple shear has overprinted cataclasis (Famin et al., 2016). Brittle deformation in the cirques of Salazie and Mafate is dominated by normal faults, whose inversion yielded a main NNE-SSW extension and a secondary perpendicular extension WNW-ESE (Famin and Michon, 2010; Chaput et al, 2014a). Minor strike-slip and thrust faulting was also observed in the vicinity of rift zones and sill zones, with principal stress axes parallel to the poles of the main intrusion trends. Chaput et al. (2014a) explained this deformation pattern by intrusion-induced stress permutations. The question remains whether stress permutations are a local mechanism restricted to the northern flank, or a general mechanism affecting the entire emerged edifice.

In comparison with Piton des Neiges, the structure of Piton de la Fournaise has been much more studied, and it is now generally agreed that the active volcano is made of two rift zones, a straight NW-SE rift zone extending west of the summit crater, and a curved rift zone with two branches connecting on the summit (Fig. 1c). Using the location of earthquakes and volcanic cones, Michon et al. (2015) showed that the NW-SE rift zone is a deep plumbing system whose seismicity extends to the base of the oceanic crust, whereas the curved rift zones is rather a shallow system in the subaerial edifice. It is also important to note that the curved rift zone delimits a sector collapse structure spreading toward the east (e.g. Froger et al., 2015).

\section{Methods}

To implement the dataset of intrusions and deformation structures already available for the cirques of Salazie and Mafate, new field investigations have been made at 44 sites in the cirque of Cilaos as well as on the outer flanks. Intrusions measured in the field are planar dikes or sills considered to have formed as extension fractures filled with magma, even though a shear component may occur in some intrusions (Berthod et al., 2016). Deformation structures include faults with slickensided surfaces and/or known sense of movement, and extension fractures. Faults and extension fractures are occasionally filled with syndeformation secondary minerals (carbonates, serpentine, oxides, zeolites). A confidence level was attributed to the observed kinematics on each deformation marker (certain, probable, supposed, unknown) using the convention of fault-slip analysis (Angelier, 1984, 1994; Delvaux and Sperner, 2003; Sperner et al., 2003). Intrusion and deformation data were manually sorted into subsets, based firstly on field-observed chronological criteria such as crosscutting relationships or the basic or differentiated composition of intrusions, and based secondly on their orientation.

Stress orientations were obtained by inversion of intrusion and deformation data following a procedure described in detail in Chaput et al. (2014a) and only briefly recalled here. This stress inversion is based on a number of assumptions (coaxial stresses and strains; small displacements on fractures compared to the volume of the rock mass; no interaction between fractures; intrusions opened as extension fractures without slip; collinear slip vector and maximum shear stress on fault planes), which have proved to be reasonable in practice (Lacombe, 2012). Intrusion and deformation data were processed separately in order to obtain independent estimates of stress orientations. The consequence of this separated processing is that intrusions only provide the direction of the least principal stress $\left(\sigma_{3}\right)$. On the other hand, the inversion of deformation structures allows reconstructing a reduced stress tensor composed of four parameters, the three orthogonal directions of principal stresses $\left(\sigma_{1} \geq \sigma_{2} \geq \sigma_{3}\right)$ and the ratio $R=\left(\sigma_{2}-\sigma_{3}\right) /$ $\left(\sigma_{1}-\sigma_{3}\right)$. For the inversion, we used the Rotational Optimization Method of the Win-Tensor software (Delvaux and Sperner, 2003). This iterative inversion method consists in finding the orientations of principal stresses that satisfy the following conditions: (1) for extension fractures, minimizing both the normal stress and the shear stress to favor opening and prevent slip; (2) for faults, maximizing the resolved shear stress magnitude and minimizing the resolved normal stress magnitude to favor slip, while minimizing the averaged deviation between observed and computed slip vectors on each fault plane. For stress tensors deduced from deformation data, the horizontal maximum and minimum stress orientations ( $\mathrm{S}_{\mathrm{Hmax}}$ and $\mathrm{S}_{\mathrm{hmin}}$ respectively) and their $1 \sigma$ standard deviation were computed from the values and uncertainties of the four parameters of the reduced stress tensor using the method of Lund and Townend (2007). As only the orientation of $\sigma_{3}$ is known from the inversion of intrusions, $\mathrm{S}_{\mathrm{hmin}}$ deduced from these data was computed as the projection of the $\sigma_{3}$ axis in the horizontal plane, keeping in mind that such projection may yield erroneous results whenever two principal stress magnitudes are close to each other.

The quality of each reduced stress tensor was estimated using two indexes, both ranging from $A$ (best) to $\mathrm{E}$ (worst). The first index, $\mathrm{QR}_{\mathrm{w}}$, rates the quality of principal stress orientations using the ranking scheme of the World Stress Map Project (Sperner et al., 2003), depending on (1) the number of data per tensor $n,(2)$ the proportion of data used in the tensor relative to the total number of data measured at each outcrop $n / n_{t}$, (3) the average slip deviation $\alpha_{w}$, (4) the average confidence level of the subset of deformation markers $\mathrm{CL}_{\mathrm{w}}$, and (5) the average type of data used for tensor determination $\mathrm{DT}_{\mathrm{w}}$, based on the usefulness of each deformation marker in stress inversion ( 1 for striated faults; 0.5 for tension fractures or dikes, and 0.25 for faults with slip sense but no striation). The second index, $Q R_{T}$, rates the quality of $R$ estimates using all the criteria of $\mathrm{QR}_{\mathrm{w}}$, plus two criteria related to the diversity of fault planes (Delvaux and Sperner, 2003). 


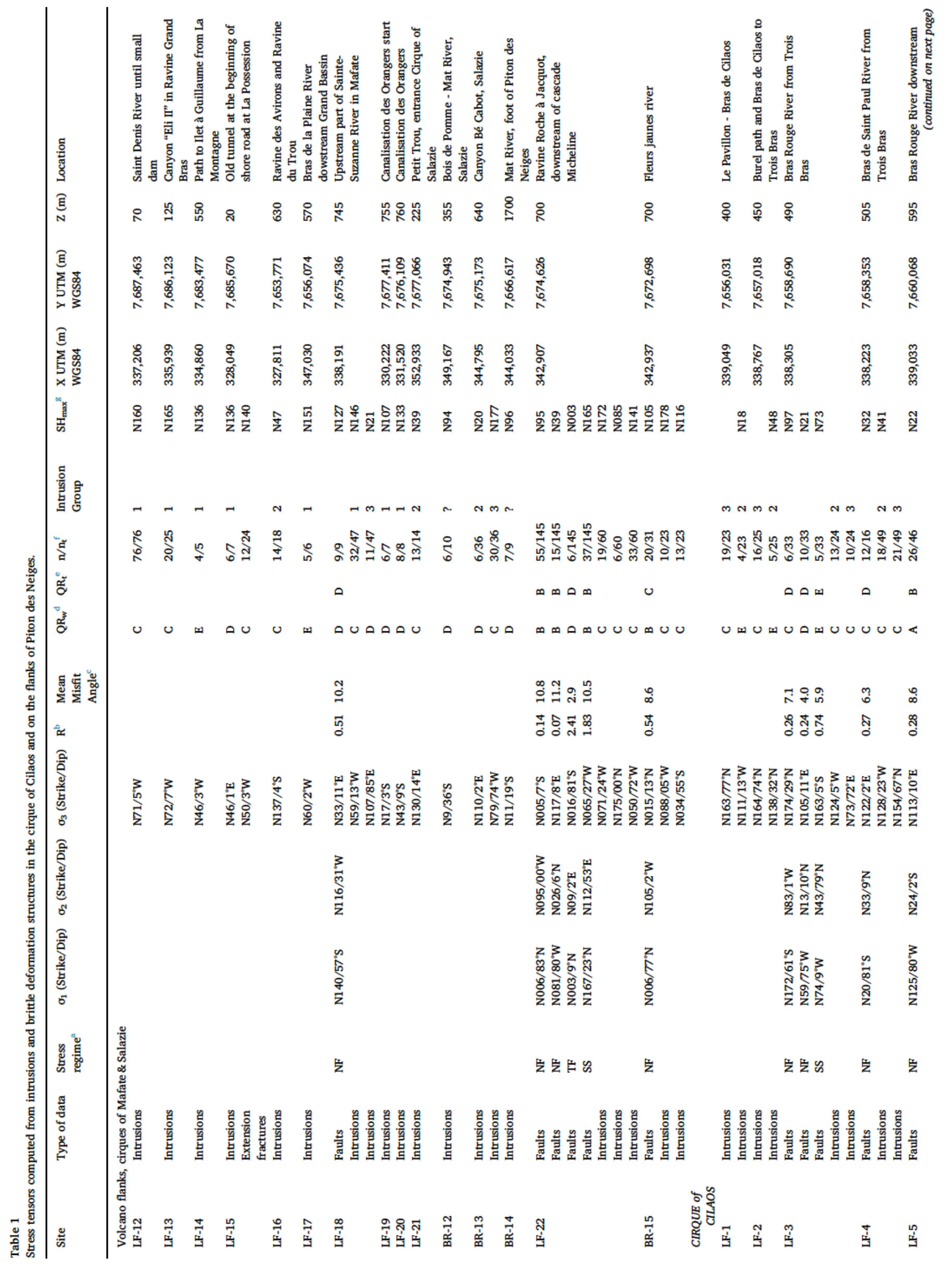




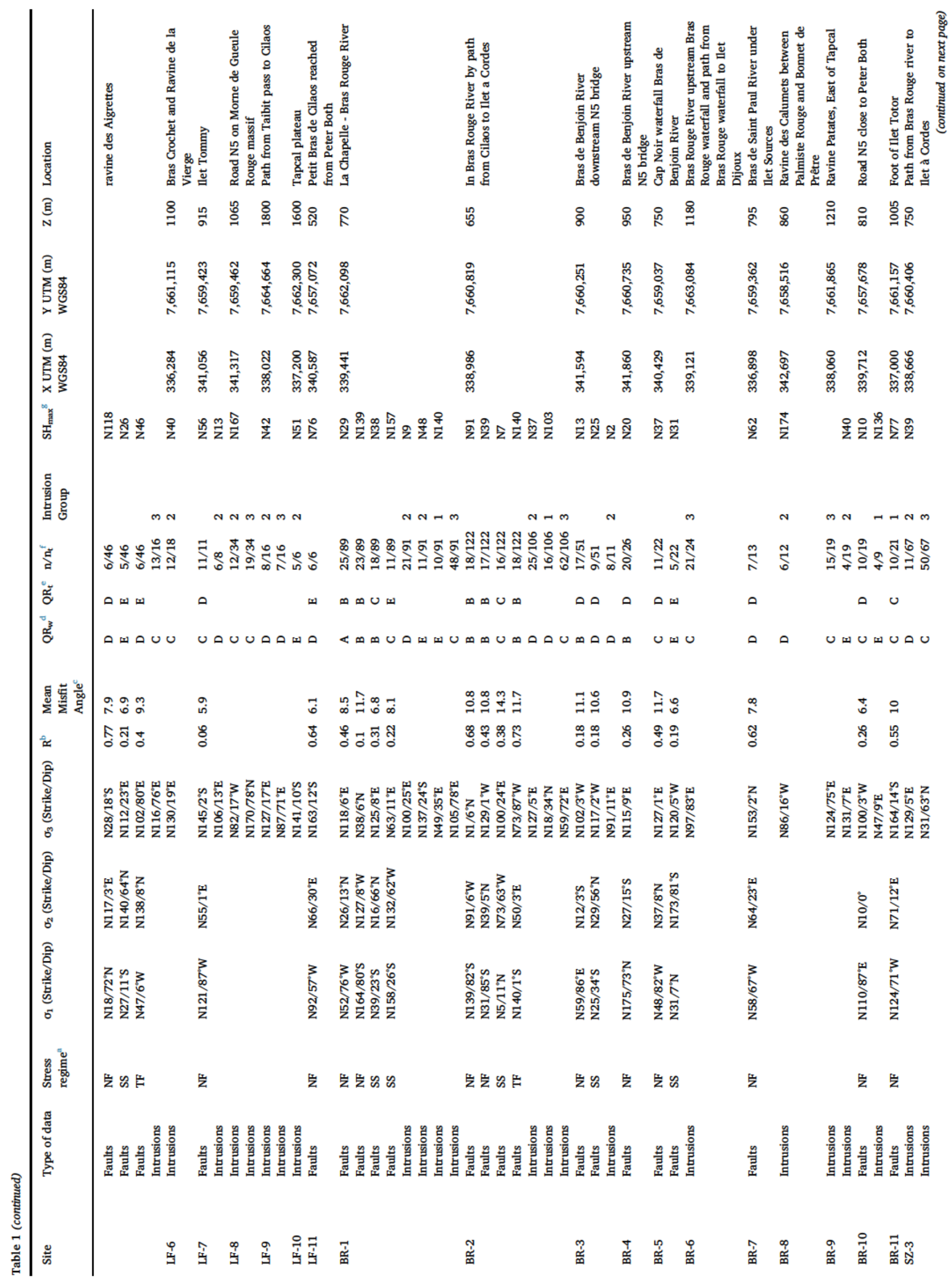




\section{Results}

\subsection{Intrusions}

1040 intrusions were measured at 34 sites (Table 1, Fig. 1b), the other 10 sites being devoid of intrusions. The complete dataset (1963 intrusions), which includes the data of Chaput et al. (2014a), is available as a Mendeley database (Chaput et al., 2017). The composition of intrusions may be classified into two categories based on their appearance in the field (Fig. 2a-b). Basic intrusions, made of dark basalt containing 0 to $35 \%$ in volume of olivine phenocrysts and variably altered in the greenschist facies, are attributed to the shield building stage of Piton des Neiges. Light-colored unaltered trachy-basalt, benmoreite, trachyte or syenite, are attributed to the differentiated stage. A noteworthy feature in the composition of differentiated intrusions is the absence of feldspar-rich rocks (mostly hawaiite) in our dataset (only one occurrence over the 1040 intrusions), despite the abundance of erupted lavas of this kind. This peculiar absence indicates that the the terminal part of the differentiated stage (190-22 ka) contributed to most of the observed differentiated intrusions. On Piton des Neiges flanks, intrusions are almost exclusively basic, except at two sites (LF16 and LF-19, Fig. 3). In the cirques of Cilaos, Salazie and Mafate, basic/differentiated intrusions represent $82 / 18 \%, 82 / 18 \%$, and $94 / 6 \%$ of the data, respectively.

As a general observation, intrusions are, as expected, more abundant in old rock units (shield building stage) than in younger ones (differentiated stage), and are also more abundant in the cirques, closer to the eruptive centers, than on the external slopes of Piton des Neiges. In detail, however, there are several other noticeable features in the repartition of intrusions. On the outer slopes, intrusions are mostly observed on the La Montagne and Etang-Salé areas. In Cilaos, the abundance of intrusions decreases from the NW to the SE part of the cirque, whereas intrusions occur all over the cirque of Salazie. In Mafate, intrusions are mostly concentrated in the northern part of the cirque whereas the southern part is nearly devoid of intrusions.

Intrusion data may be also sorted into three populations based first on their dip (Fig. 4), and then on their and strike (Fig. 3, 5), each population containing both basic and differentiated intrusions. The first population (Group 1) consists in subvertical dikes (i.e. with a dip $\geq 70^{\circ}$ ) oriented NW-SE (Fig. 2c). This population is mostly concentrated in the northern half of the cirque of Mafate, is abundant in Salazie, but is scarce in Cilaos (Figs. 3, 5). The second population of intrusions (Group 2) is made of dikes trending NNE-SSW with a dip $>45^{\circ}$ (Fig. 2a). This population is abundant in the cirque of Cilaos, present in Salazie, but is almost absent in Mafate. The third population (Group 3) is made of sills and intrusions with a dip $\leq 45^{\circ}$ (Fig. 2b, d, 4). On the one hand, Group 3 is the dominant population of intrusions in the cirques of Cilaos and Salazie where it represents $57 \%$ and $47 \%$ of the data, respectively. On the other hand, Group 3 intrusions are absent from the flanks of Piton des Neiges, and have been observed only at two sites in the cirque of Mafate. Importantly, Group 3 intrusions have almost opposite dips in Cilaos (toward the SW) and in Salazie (toward the NNE). Low-dipping intrusions are sometimes isolated, but more frequently form piles of several tens of magma injections (Fig. 2d). Three piles are observed in the cirque of Cilaos, the lowermost one ( $\sim 50$ intrusions) at $750-800 \mathrm{~m}$ above sea level (a.s.l.), the intermediate one $(\sim 20$ intrusions) at $1050-1100 \mathrm{~m}$ a.s.l., and the uppermost one ( $\sim 30$ intrusions $)$ at $1200-1300 \mathrm{~m}$ a.s.l..

Mutual crosscutting among basic intrusions of the three populations is observed. Group 1 or Group 2 subvertical intrusions are also sometimes inflected into Group 3 subhorizontal intrusions (Fig. 2d). Both observations indicate that the three populations of intrusions occurred during a common time interval. Differentiated alkaline intrusions of the three groups crosscut basic transitional intrusions. 

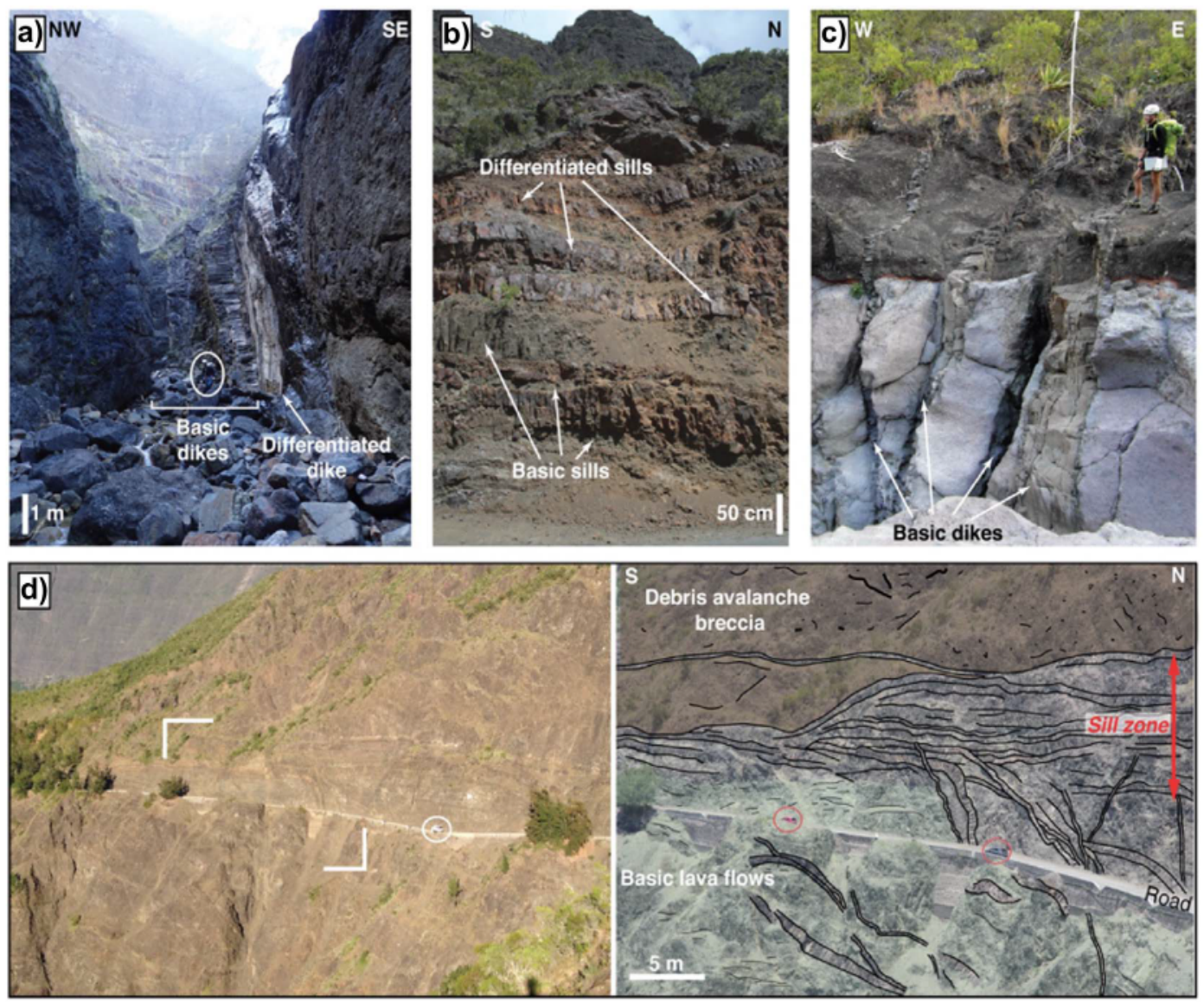

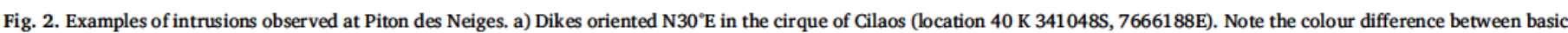

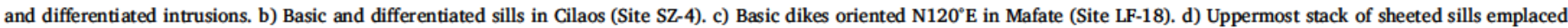
between lavas flows and basic breccia (site SZ-4). Note the reorientation of $\mathrm{N} 30^{\circ} \mathrm{E}$ basic dikes into sills and the mutual crosscutting relationship between dikes and sills.

\subsection{Deformation structures}

Deformation structures and their inversion are provided in Figs. 3 and 6 and in Table 1. A total of 725 new deformation data at 18 sites was added to the already existing dataset of Chaput et al. (2014a). As for intrusions, the entire deformation dataset (1545 data) is available in the Mendeley database (Chaput et al., 2017). Deformation on the volcano flanks has been observed at five sites, only one of which (LF-15) yielded enough data for paleostress inversion (Fig. 3, Table 1). This site LF-15, on the NW flank of Piton des Neiges, displays NW-SE extension fractures consistent with $\sigma_{3}$ oriented $N 50 / 3^{\circ} \mathrm{W}$. Deformation data are also scarce in the cirque of Mafate, among which only one site (LF-18) allowed a paleostress inversion, yielding an extension with $\sigma_{3}$ oriented $\mathrm{N} 33 / 11^{\circ} \mathrm{E}$.

On the contrary, deformation structures are extremely abundant in the cirque of Cilaos and mostly occur in hydrothermally altered basic rocks of the shield-building stage of Piton des Neiges (Fig. 6). In this area, deformation is dominated by normal faults $(61.6 \%$ of the total dataset), which may be sorted in two populations. The first population (14 sites, $36.6 \%$ of the data) is compatible with an E-W to NW-SE extension. The second population of normal faults (5 sites, $13.5 \%$ of the data) is compatible with a N-S to NNE-SSW extension. Strike-slip faults were found at 7 sites ( $14.6 \%$ of the data), and their inversion yielded paleostress tensors with E-W to WNW-ESE $\sigma_{3}$ axes except for two tensors (N163/5 ${ }^{\circ} \mathrm{S}$ and $\mathrm{N} 63 / 11^{\circ} \mathrm{N}$ at sites BR-1 and $\mathrm{LF}-3$, respectively). Reverse faults were found at 3 sites (5.5\% of the data, sites BR-2, SZ-4, and LF-5) yielding paleostress tensors with NNE-SSW or NW-SE $\sigma_{1}$ axes. These three sites of compressional deformation are located near or within low-dipping intrusion piles (Fig. 6; see also Fig. 2e, 3d in Chaput et al., 2014a, and Fig. 2 in Famin et al., 2016).

Contradictory crosscutting relations were observed among deformation microstructures of each type of paleostress tensor. Mutual crosscut relationships were also evidenced between brittle deformation and basic intrusions, but fewer deformation structures crosscut the differentiated intrusions.

\section{Discussion}

\subsection{Organization of intrusions}

The results of this study, added to the data of Chaput et al. (2014a), provide an integrated view of how intrusions are organized in the emerged part of Piton des Neiges (Fig. 7). Firstly, intrusions are heterogeneously distributed in the volcano. The southern and northern halves of the cirque of Mafate, for instance, display rock units of same age, yet very contrasted intrusion densities. Similarly, the cirque of Cilaos also presents decreasing intrusion densities from the west to the east. Secondly, the three groups of intrusion orientations also show a heterogeneous repartition, Group 1 intrusions being mostly found on the northern half of Piton des Neiges, Group 2 on the southern half, and Group 3 exclusively in the cirques. This distribution of intrusion abundance and orientations highlights the existence of three main concentration zones of intrusions (Fig. 7). The first, most obvious concentration zone is made of the Group 1 NW-SE dikes running from the cirque of Salazie through the northem half of Mafate. This concentration zone is interpreted as accounting for a single curved rift zone, 5-10 km wide, hereafter called the "Salazie-La Montagne rift zone". This rift zone bends and widens from $N 110^{\circ} \mathrm{E}$ in Salazie to 


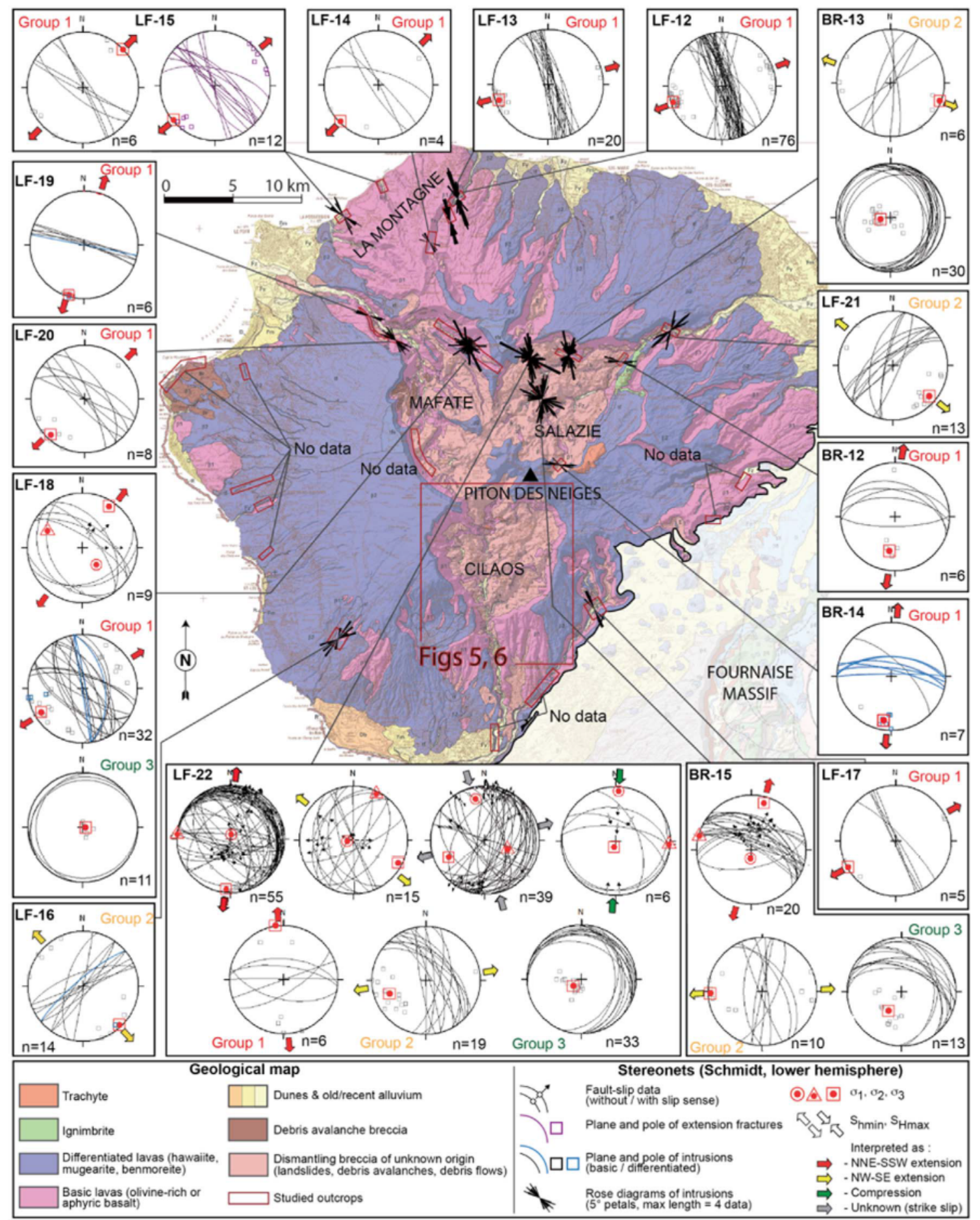

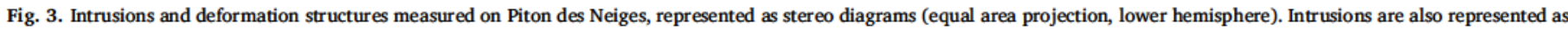

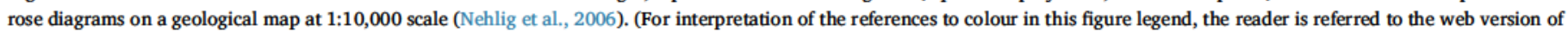
this article.)

$\mathrm{N} 160^{\circ} \mathrm{E}$ toward the La Montagne Massif. There is no evidence that this rift zone extends northward to the submarine part of the edifice. An outcrop in the northern cliff of Mafate provides age constraints on the Salazie-La Montagne rift zone (site Pah14, Fig. 2a in Chaput et al., 2014a). This outcrops displays a discordance at half height in the cliff, separating a lower unit of lavas flows heavily intruded by N120 $140^{\circ} \mathrm{E}$-trending dikes from an upper unit of lavas without intrusions. The top of the cliff, belonging to the upper unit, has been dated at 1.3 Ma (Salvany, 2009). This, and the dominantly basic composition of the dikes, suggests that the NW side of this rift zone was essentially active during the early shield building stage before $1.3 \mathrm{Ma}$, whereas the SE side remained active in the differentiated stage. The eastern prolongation of this rift zone cannot be defined due to the lack of valley incision in this region of Piton des Neiges.

The second main concentration zone is made of NNE-SSW dikes (Group 2) from the cirque of Cilaos, also found to a lesser extent in Salazie. This intrusion trend is consistent with the $N 30^{\circ} \mathrm{E}$ rift zone evidenced by the alignment of late eruptive vents above Etang-Salé and by the ridge observed offshore (Lénat and Labazuy, 1990). This second rift zone, hereafter called the "Etang-Salé rift zone", is $\sim 5 \mathrm{~km}$ wide, 


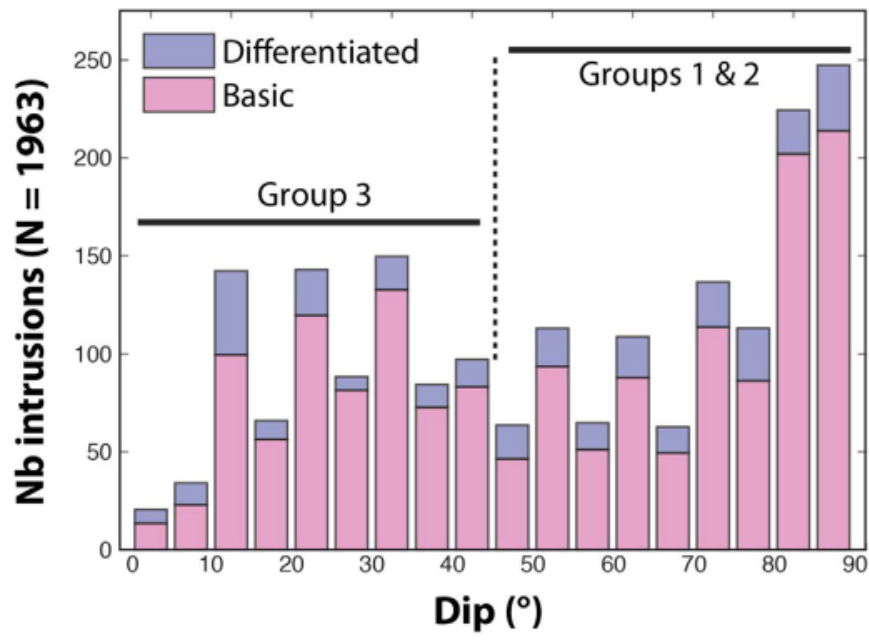

Fig. 4. Histogram of intrusion abundance as a function of their dip angle. Intrusion data are subdivided into groups according to peak abundances, Groups 1 and 2 standing for steeply-dipping intrusions (dip $>45^{\circ}$ ) and Group 3 for low-dipping intrusions (dip $\leq 45^{\circ}$ ).

passes through the present-day summit of Piton des Neiges, and intersects the Salazie-La Montagne rift zone in the cirque of Salazie, about $3 \mathrm{~km}$ north of the present-day summit of Piton des Neiges (Fig. 7). The Etang-Salé rift zone is thus a major structure that affects the entire submarine and subaerial edifice. The Etang-Salé rift zone may also continue northward in Salazie, but intrusions become less abundant and their orientation less homogenous in this area. The occurrence of basic as well as differentiated intrusions, the age of the offshore ridge $(2.48 \pm 0.05 \mathrm{Ma}$ (Smietana, 2011)), and the unknown yet probably very recent age of the late eruptive vents $(\leq 250 \mathrm{ka})$, suggest that the Etang-Salé rift zone has been active in the shield building stage and in the terminal stage of Piton des Neiges volcano.

The third injection trend is made of the low-dipping intrusions (Group 3) dominant in the cirques of Cilaos and Salazie. Since the majority of low-dipping intrusions concentrate in narrow zones (between 750 and $1300 \mathrm{~m}$ a.s.1.), they can be regarded to constitute two sill zones. The dual composition of low-dipping intrusions (basic magmas altered in the greenschist facies and unaltered differentiated magmas) implies that the sill zones experienced two main phases of activity, one during the emerged shield building stage ( $>2.2 \mathrm{Ma}$ to $430 \mathrm{ka}$ ), the other during the terminal stage of Piton des Neiges after $190 \mathrm{ka}$.

In summary, the two perpendicular rift zones and the two sill zones shared common periods of activity during the shield building stage. The activity of the Salazie-La Montagne rift zone faded out before the differentiated stage. The puzzling absence of feldspar-rich intrusions in our dataset implies that the large volumes of feldspar-rich lavas erupted during the period 350-190 ka were fed by a now-hidden central vent, and not by the Etang-Salé rift zone nor by the sill zones. In comparison, the terminal trachytic stage (190-22 ka) produced fewer lavas yet much more intrusions in a shorter time lapse, with rejuvenation of both the Etang-Salé rift zone and the two sill zones.

\subsection{Deformation pattern}

Field investigation at the scale of the edifice also reveals that deformation is widely observed in the cirques of Cilaos and Salazie, and in the northern part of Mafate, whereas it is absent from the southern part of Mafate and from the outer flanks (Fig. 8). This heterogeneous repartition of deformation structures is in match with that of intrusions.

The predominance of normal faults among deformation structures implies that the emerged edifice has been essentially affected by extension. In the La Montagne Massif and the cirque of Mafate, extension is mostly directed NE-SW, a direction perpendicular to the Salazie-La
Montagne rift zone. In the cirque of Cilaos, the dominant extension trends NW-SE, a direction perpendicular to the Etang-Salé rift zone. In the cirque of Salazie, extension splits into a dominant NNE-SSW orientation and a secondary NW-SE orientation. Wherever found, the strike-slip faults yield strike-slip stress regimes with $\sigma_{3}$ axes in general agreement with either of the two extensions. The thrust faults observed in the vicinity of low-dipping intrusion piles in Salazie and Cilaos suggest that compressional stresses occurred within the sill zones or close to them, in kinematic consistency with the subvertical $\sigma_{3}$ axis required for opening low-dipping intrusions. In this respect, it is likely that the lithological boundaries in which some of the sill stacks are injected participated to a local reorientation of $\sigma_{3}$ to the vertical.

Taken together, intrusion and deformation data are not only consistent in their spatial distribution, but are also mechanically consistent (Fig. 9): the NE-SW extension of the La Montagne Massif and the cirque of Mafate is correlated to the Salazie-La Montagne rift zone (Fig. 9a). The dominant NW-SE extension of the cirque of Cilaos may be attributed to the Etang-Salé rift zone (Fig. 9b). The two extensions of the cirque of Salazie may be attributed to a dual influence of the two rift zones in the vicinity of their junction (Fig. 9c). Finally, the compression found in Cilaos and Salazie is also mechanically consistent with the development of the sill zones (Fig. 9b-c). The stress states that led to the development of the preferential intrusion trends are thus also responsible for the brittle deformation of the emerged edifice. The two independent dataset both show that stress states alternated during the lifetime of Piton des Neiges between three perpendicular directions of $\sigma_{3}$ : two nearly horizontal (NNE-SSW and NW-SE) and one nearly vertical (Fig. 9d).

\subsection{Implications for the volcano-tectonics of Piton des Neiges}

Our study of intrusions and deformation brings new constraints on the geometry of the plumbing system and the stresses that controlled this geometry. It is firstly worth noting that the distribution and orientation of intrusions do not match a cone sheet structure (i.e. centrally-inclined intrusions), because most of the measured intrusions (dikes as well as sills) are inclined outward (i.e. toward the sea). The majority of intrusions can neither be considered as ring dikes or radial dikes because they are not homogenously spread around an eruptive center. Cone sheets, ring dikes and radial dikes being classically interpreted as due to pressure variations in the magma chamber (e.g. Gudmundsson, 2006; Acocella and Neri, 2009), we conclude that magma pressure fluctuations in the reservoir did not primarily control the distribution and geometry of intrusions at Piton des Neiges.

Instead, intrusion and deformation data suggest that three stress fields with perpendicular principal stress axes alternated at the scale of the emerged edifice. Chaput et al. (2014a) already noticed this pattern in the cirques of Salazie and Mafate, and proposed a model in which permutations of principal stress axes could occur within a dominantly extensional stress regime, provided that the stress increase due to the injection of pressurized magma is not released by edifice deformation. This concept, based on the general idea that intrusions induce local modification of the stress field (e.g. Geoffroy et al., 1993; Kühn and Dahm, 2008; Lehto et al., 2010; Tibaldi and Bonali, 2017), is adapted from the model of Vigneresse et al. (1999). In this model, the pressure of magma intrusions may generate cyclic permutations of principal stress axes. Each cycle starts under a regional extension (the dominant stress regime at Piton des Neiges) by repeated dike intrusions perpendicular to $\sigma_{3}$. Each injection has the effect of increasing the magnitude of $\sigma_{3}$ by the value of the magma pressure (P), and $\sigma_{2}$ only by $\nu . P(v$ being Poisson's coefficient). Multiple intrusions would thus result in the magnitude of $\sigma_{3}$ eventually exceeding that of $\sigma_{2}$, causing the stress axes of $\sigma_{2}$ and $\sigma_{3}$ to switch into an extensional stress field perpendicular to the initial extension, favorable to perpendicular dike injections. When intrusive activity pursues, stress increases due to magma pressure may yield new permutations into strike-slip regimes (when one of the 


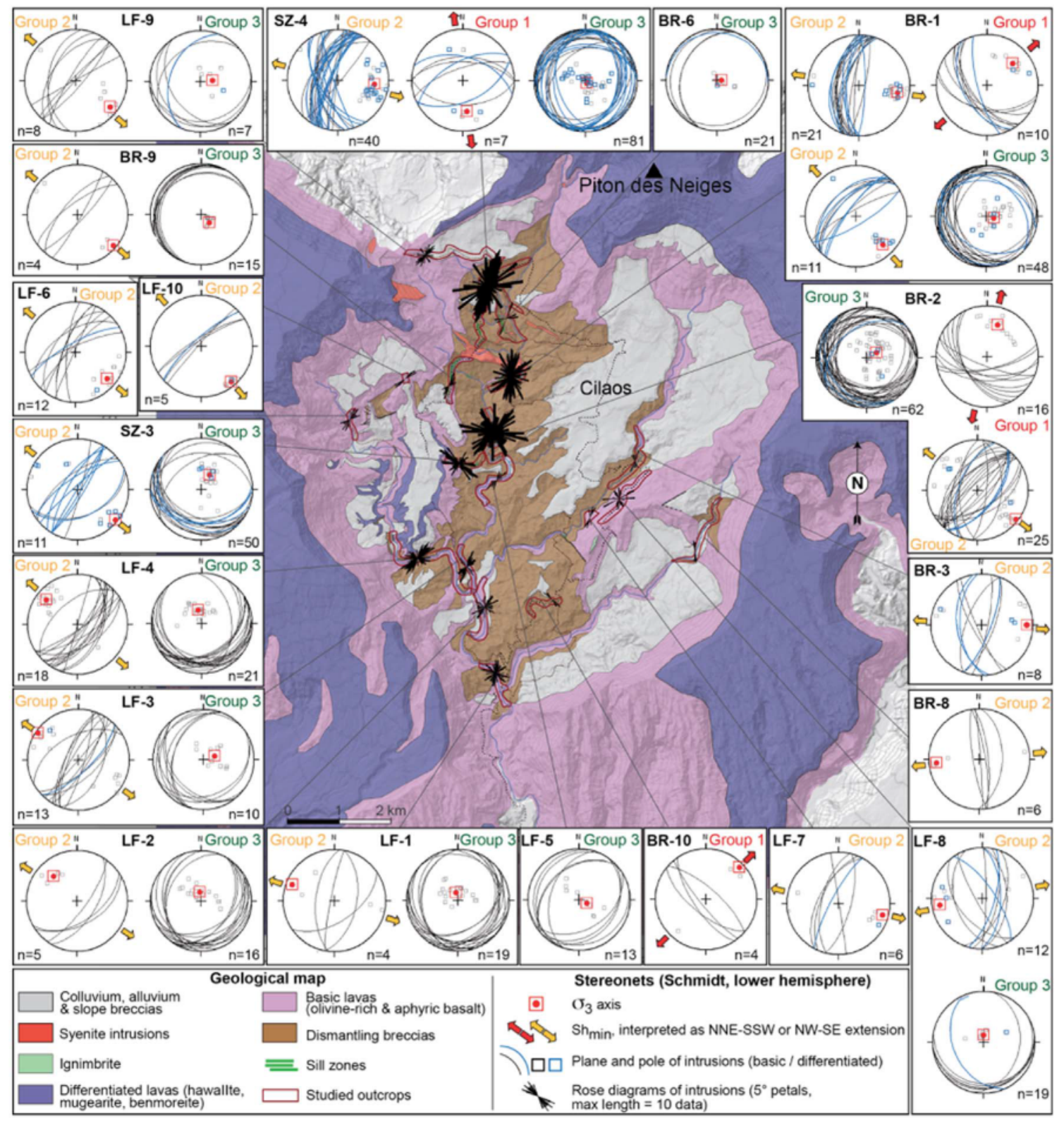

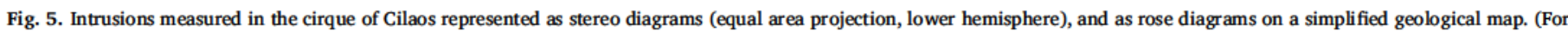
interpretation of the references to colour in this figure legend, the reader is referred to the web version of this article.)

horizontal stress overcome the vertical stress) then compression. This final compressional stress state would produce low-dipping intrusions (when both horizontal stresses exceed the vertical stress), eventually acting as slip surfaces promoting flank displacement, thus restoring the initial extensional stress state in the edifice and starting a new permutation cycle.

This model requires the intrusion and deformation data to fulfill the following conditions: (1) the perpendicular intrusion trends and the different paleostress tensors must have occurred intermittently during the same time period, (2) the different paleostress tensors must share subparallel stress axes within error, (3) stress permutations occur due to repeated intrusions, so the occurrence of incompatible paleostress tensors should be spatially correlated to the vicinity of heavily intruded zones, (4) the differential stress $\left(\sigma_{1}-\sigma_{3}\right)$ must decrease from extensions to compressions (see Chaput et al., 2014a for details), and (5) for each paleostress tensor, two of the three principal stresses must be close in magnitude to allow permutation.

These conditions are fulfilled in the cirques of Salazie and Mafate
(Chaput et al., 2014a), but need to be checked with the new, larger dataset, wherever intrusion and deformation data are available at the same sites. This is the case in the cirque of Cilaos, where the three perpendicular intrusion trends mutually crosscut each other, as do intrusions and deformation structures. This confirms the validity of condition (1) described above.

For a given site, the stress tensors producing normal, strike-slip and reverse faults share similar orientations of principal stress axes (see, for example, sites BR-1 and LF-5). Paleostress orientations are also parallel with any of the $\sigma_{3}$ axes deduced from the three intrusion trends. There is thus an excellent consistency of principal stress orientations from the different data, suggesting that condition (2) is also fulfilled.

The area of maximum intrusion density in Cilaos (Bras Rouge River, from sites BR-1 to LF-5, and site SZ-4) also corresponds to the area of maximum abundance of deformation structures, where extension, strike-slip and compression are evidenced all together. Deformation density is thus spatially correlated with intrusion density, which substantiates condition (3). 


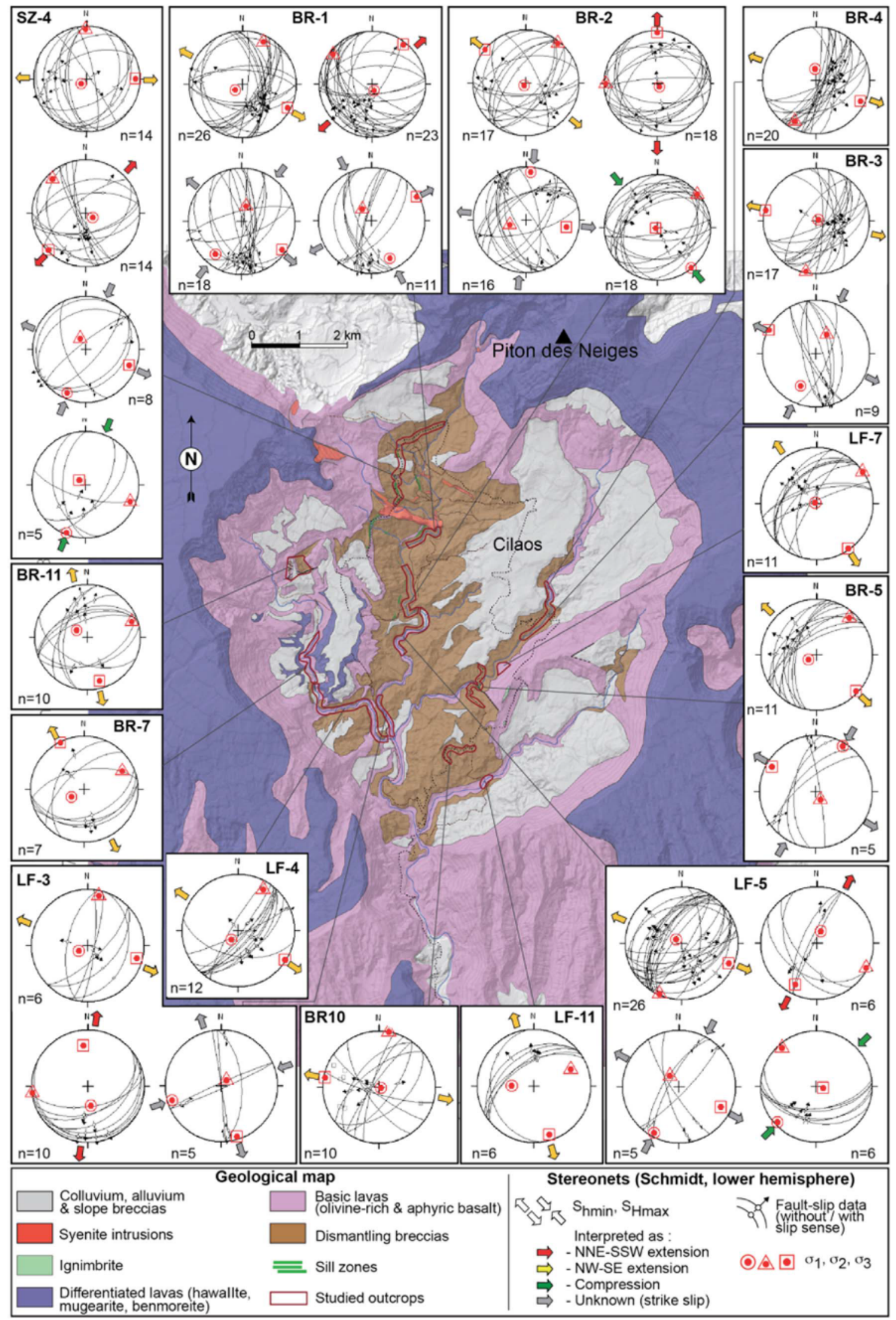

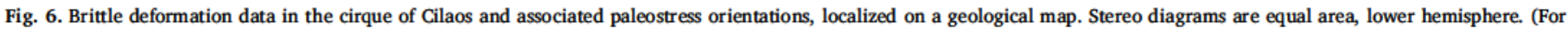
interpretation of the references to color in this figure legend, the reader is referred to the web version of this article.) 


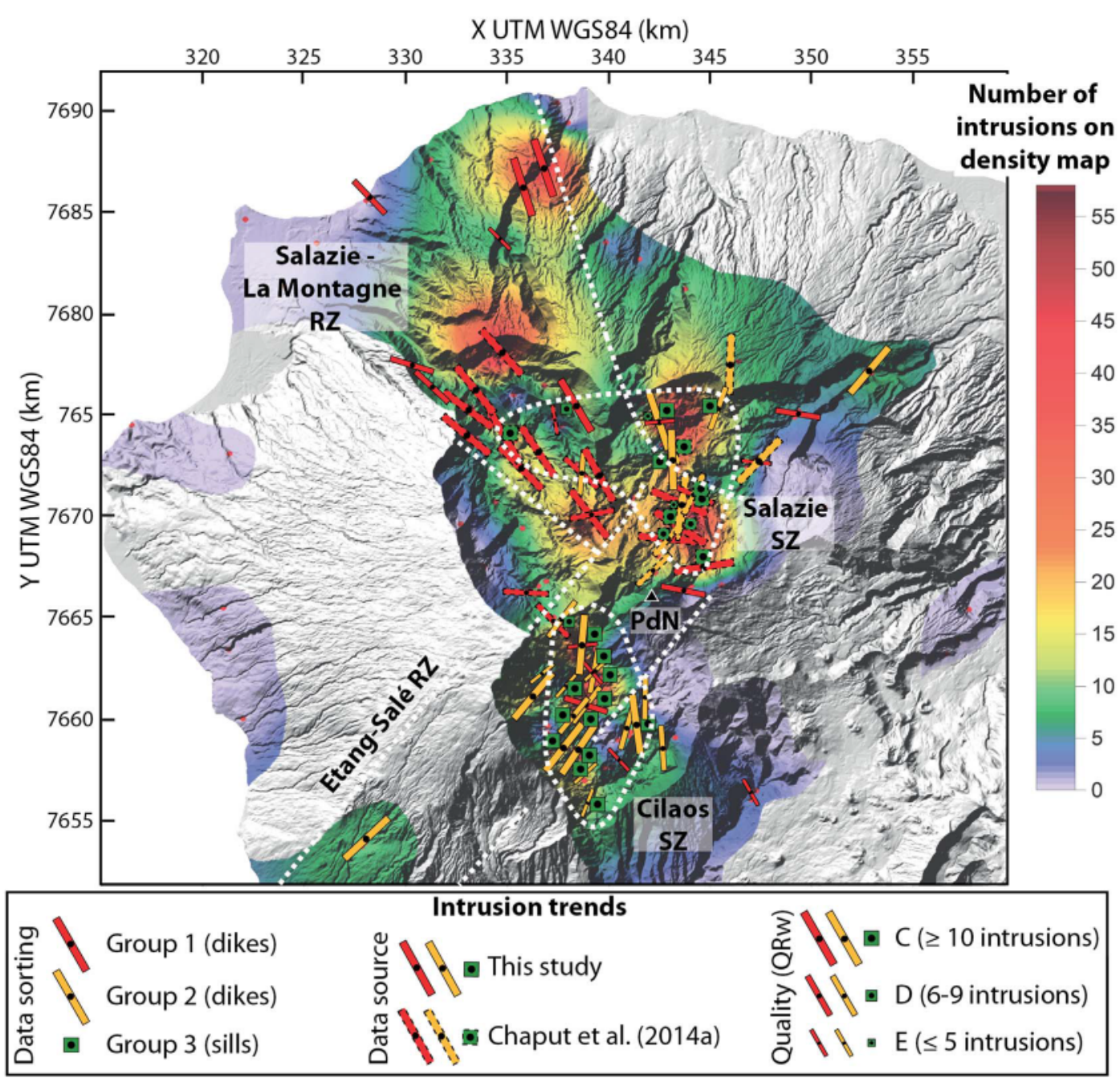

Fig. 7. Averaged orientation of intrusions at Piton des Neiges, reported on a heat map of intrusion densities. White dotted lines delimit the rift zones and sill zones.

In theory, repeated stress permutations cause the differential stress $\left(\sigma_{1}-\sigma_{3}\right)$ to progressively decrease, which prevents fault neoformation and reduces their reactivation. In Cilaos, normal, strike-slip and reverse faults represent 257,105 , and 36 of the measured deformation structures, respectively, indicating that the number of measured faults decreased from extension to compression. Moreover, fault-slip data consistent with the dominant extension NW-SE display a majority of neoformed faults (whose attitude is that of conjugate faults created by this stress tensor, e.g. sites BR-3, BR-4, BR-7, BR-11, and LF-5 in Fig. 6), while data consistent with the minor extension, strike-slips and compressions display a majority of reactivated faults (whose striae is not in the $\left(\sigma_{1} ; \sigma_{3}\right)$ plane, e.g. sites BR-1 to BR-5, BR-10, LF-3, and LF-5). This suggests that the differential stress indeed decreased from extension to compression, as expected in condition (4).

Finally, the magnitudes of the principal stresses are also important parameters for stress permutations. The ratio $\mathrm{R}=\left(\sigma_{2}-\sigma_{3}\right) /\left(\sigma_{1}-\sigma_{3}\right)$ obtained by inversion of fault-slip data provides information about the relative magnitude of $\sigma_{1}, \sigma_{2}$, and $\sigma_{3}$. Low $R$ values $(0 \leq R<0.5)$ and high $R$ values $(0.5<R \leq 1)$ indicate that $\left(\sigma_{2} ; \sigma_{3}\right)$ and $\left(\sigma_{1} ; \sigma_{2}\right)$, respectively, are close in magnitude and their axes prone to permute (Angelier, 1984, 1994). Our extensional tensors in Cilaos display an average $R$ value of 0.38 , showing that the two horizontal stresses $\sigma_{2}$ and $\sigma_{3}$ were close in magnitude and their axes favorable to switch. The situation is similar for strike-slip tensors, for which the low $\mathrm{R}$ value $(0.37$ in average) suggests $\sigma_{2}$ and $\sigma_{3}$ permutations. The average $\mathrm{R}$ value for compressions is 0.5 , an intermediate value which does not fit with our stress permutation interpretation. This, however, can be explained by the few data used in the computation of two of the three compressional tensors, which provided large uncertainties in the calculation of R. For the third compressional tensor (site BR-2), obtained from a larger data set $(n=18)$ and displaying a good quality rating $\left(Q_{w} \geq C\right)$, the $R$ value is 0.73 in consistency with $\sigma_{1}$ and $\sigma_{2}$ permutations.

To conclude, the stress permutation model of Chaput et al. (2014a) is thus fairly adapted to describe in detail the pattern of intrusions and deformation structures at the scale of the emerged edifice.

\subsection{Implications for the spreading mode and strength of La Réunion volcanoes}

An important question, concerning the rheology of La Réunion volcanoes and their related mode of spreading, may be discussed in the light of these new results. Many of the escarpments of Piton des Neiges have been interpreted as faults delimiting grabens due to gravitational spreading. Based on analogue modeling, Oehler et al. (2005) proposed that the cirques of Piton des Neiges could be spreading structures. More recently, Delcamp et al. $(2008,2012)$ attributed to Piton des Neiges a radial mode of spreading owing to the star or flower shape of escarpments, and to Piton de la Fournaise an asymmetric sector collapse mode of spreading owing to its horse-shoe shaped rift zones (Figs. 1c; 10). Le Friant et al. (2011) also proposed contrasted behaviors for the two volcanoes, radial spreading for Piton des Neiges and sector collapse for Piton de la Fournaise. 


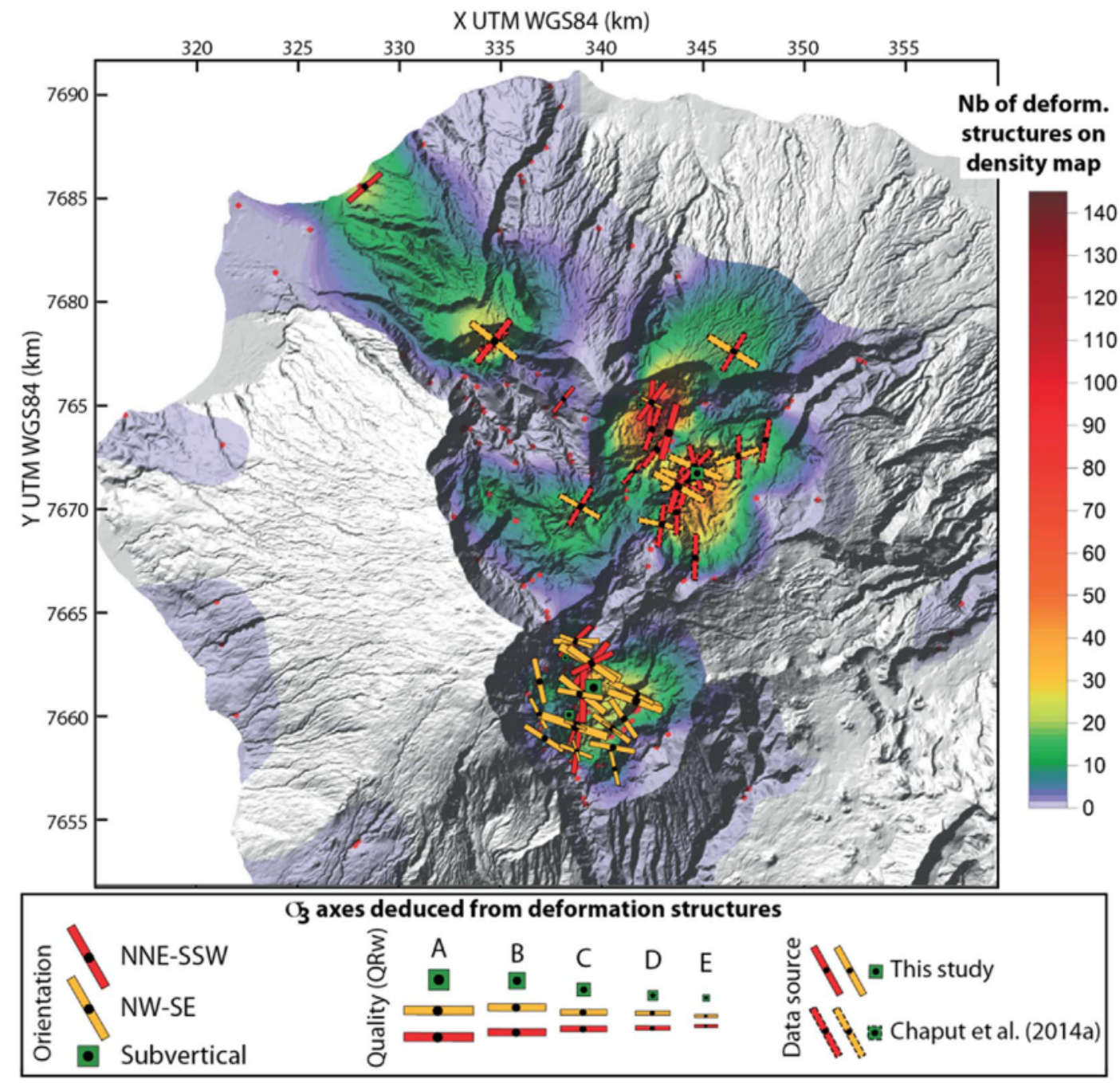

Fig. 8. Orientation of $\sigma_{3}$ axes computed by inversion of deformation structures, reported on a heat map of deformation structure densities.

Our study shows that the preferential injection zones and deformation structures of Piton des Neiges do not follow the main geomorphological features. Thus, the geomorphic study of this volcano may be misleading to interpret its mode of spreading. Spreading does occur at Piton des Neiges, as confirmed by the predominance of normal faulting, but along two perpendicular directions rather than in a radial fashion (Fig. 10). The first spreading direction occurs toward the NNE and affects a sector collapse on the NE flank of Piton des Neiges, delimited on the west by the Salazie-La Montagne rift zone. The compressional deformation structures at the northem offshore base of the edifice described by Le Friant et al. (2011) suggest that this sector collapse extends seaward to the submarine edifice. The second spreading direction, oriented NW-SE and related to the Etang-Salé rift zone, is responsible for the extensional deformation found in the cirque of Cilaos. In consequence, Piton des Neiges shares common volcanotectonic features with Piton de la Fournaise, both volcanoes undergoing a sector collapse delimited by horse-shoe rift zones connected to a straight rift zone (Fig. 10). For both volcanoes, the straight rift zone affects the entire edifices whereas the horse-shoe-shaped rift zones are only evidenced on the emerged volcanoes. This similar volcano-tectonics suggests a similar mechanical behavior for the two edifices.

Radial spreading has been reproduced experimentally with a ductile layer (like a weak cumulative body or a hydrothermal system) incorporated into a brittle edifice (Type I volcanoes in Delcamp et al., 2008, 2012). On the other hand, analogue modeling of a brittle edifice built above a ductile layer (Type II in Delcamp et al., 2008, 2012) obtained asymmetric spreading with perpendicular structures and sector collapse. The asymmetry of Piton des Neiges suggests that the rheology of this volcano is closer to the the latter kind, as is Piton de la Fournaise. This implies that the spreading of the two volcanoes is more likely controlled by a deforming layer underneath La Réunion, for instance the oceanic crust, than by ductile rocks such as hypovolcanic complexes or hydrothermal systems within the edifices.

The excellent match of the stress permutation model with intrusion and deformation data supports the idea that La Réunion volcanoes are essentially strong edifices, as opposed to Mount Etna or Hawaiian volcanoes that spread under their own weight. Indeed, stress permutations occur when the pressure increase due to magma intrusions cannot be released by plastic edifice deformation. This implies that the rate of dike opening is greater than the rate of flank displacement, and thus that the repeated injection of magma into intrusion zones (dikes or sills) is a dominant mechanism of flank instability over gravitational spreading.

In this respect, many recent studies emphasize the role of sill intrusions in promoting flank instability. Numerical modeling shows that low-dipping intrusions in a homogeneous brittle edifice or along a detachment may both trigger lateral flank displacement (Cayol et al., 2014; Chaput et al., 2014b). Field evidence of co-intrusive flank sliding due to a sill intrusion has been found at Piton des Neiges (Berthod et al., 2016). It is also generally agreed that the April 2007 co-eruptive sector flank displacement of Piton de la Fournaise was triggered by a sill (Clarke et al., 2013; Cayol et al., 2014; Got et al., 2013; Froger et al., 


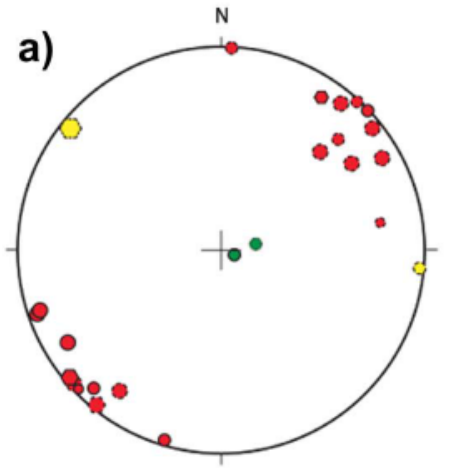

Mafate and La Montagne

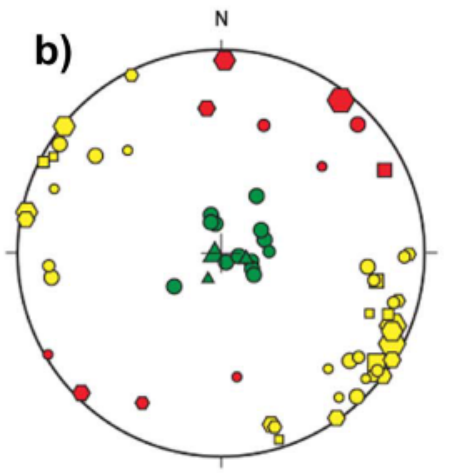

Cilaos and Etang-Salé

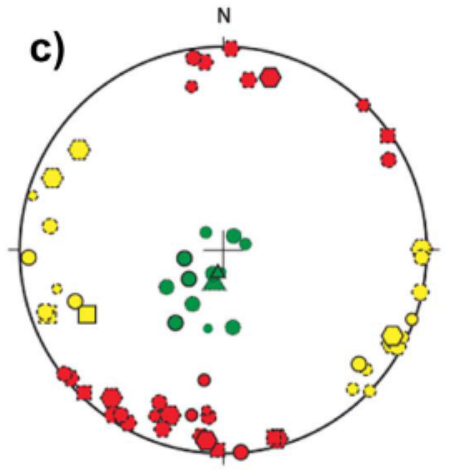

Salazie

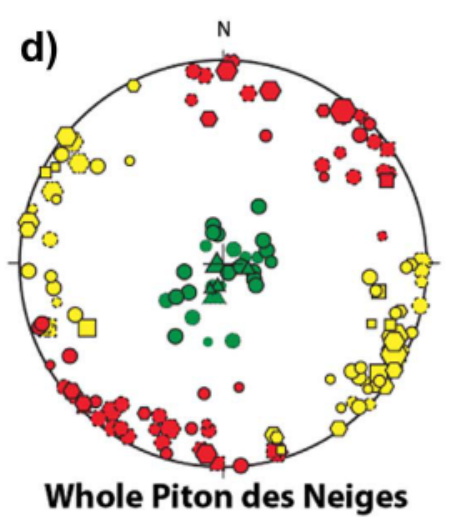

\begin{tabular}{|c|c|c|c|c|}
\hline \multirow{7}{*}{ 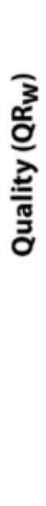 } & \multicolumn{4}{|c|}{ Stress regime } \\
\hline & A & $\mathrm{O}$ & $\square$ & \\
\hline & B & 0 & $\square$ & \\
\hline & C & 0 & 口 & \\
\hline & $\mathrm{D}$ & 0 & 口 & \\
\hline & $\mathrm{E}$ & $\circ$ & 口 & \\
\hline & & 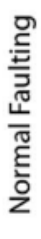 & 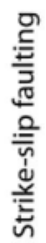 & 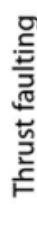 \\
\hline
\end{tabular}

Compatibility
NNE-SSW extension
N NW-SE extension
$\triangle \quad$ Compression
Data source
$0 \triangle \triangle$ This study
C Chaput et al. (2014a)

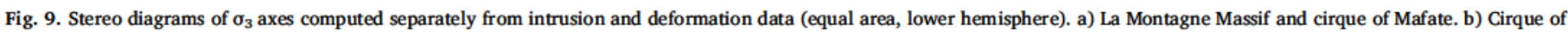
Cilaos and slopes of Etang-Salé. c) Cirque of Salazie. d) Total set of $\sigma_{3}$ axes for Piton des Neiges.

2015). Flank displacement decayed in the post-eruptive period after sill intrusion, likely in the form of a slow-slip along a detachment (Tridon et al, 2016). Sill intrusion producing flank failure has been also reported at Stromboli volcano in Italy (Casagli et al., 2009). Following these studies, we suggest that repeated injections of sills into sill zones are important in controlling the sector collapse spreading of La Réunion volcanoes, otherwise behaving as brittle edifices.

It has also been proposed that the kilometer scale plutonic complex played a role in the deformation and spreading of Piton des Neiges. Gailler and Lénat (2012) suggested that the subsidence of this plutonic complex is at the origin of the cirques, although they also acknowledge the lack of geological evidence in support of their model. For the time being, we cannot exclude a participation of pluton subsidence to the extensional deformation documented here, even though it does not explain why extension and rift zones are oriented in a perpendicular fashion instead of being radial. Pluton subsidence might also play a role in the development of sill zones by fostering vertical opening, yet it should yield centrally-inclined intrusions instead of the outward dipping ones observed in our study. Delcamp et al. (2012) proposed that the growth and spreading of this plutonic complex was responsible for the formation of the cirques as grabens and the deformation observed in them (Fig. 12 in Delcamp et al., 2012). This interpretation is kinematically consistent with the occurrence of outward-dipping intrusions and with some of the observed deformation structures, but faces a chronological problem. Indeed, microstructural investigation shows that the outcropping portion of plutonic complex has not experienced significant ductile creep since its cooling below the solidus of the gabbro (Famin et al., 2016). According to ${ }^{40} \mathrm{Ar} /{ }^{39} \mathrm{Ar}$ dating, the gabbro passed the $300^{\circ} \mathrm{C}$ temperature at $\sim 2.2 \mathrm{Ma}$ and hence the solidus at an older age (Berthod, 2016). As discussed above and in Chaput et al. (2014a), the activity of the rift zones and deformation encompasses the shield and differentiated stages. The present-day cirques are also

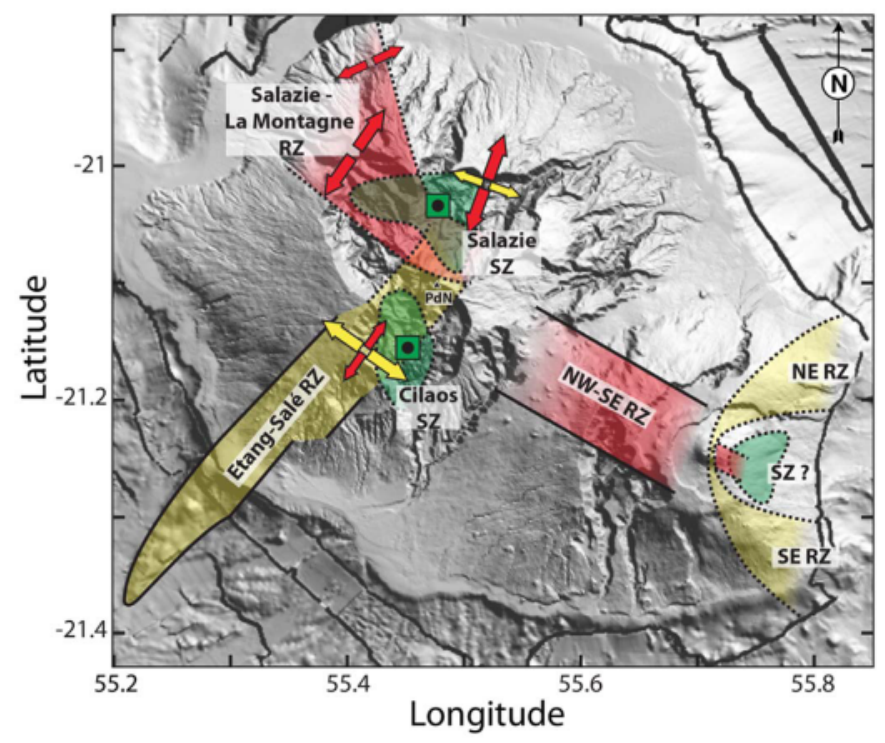

Fig. 10. Summary of volcano-tectonic structures evidenced at Piton des Neiges and Piton de la Fournaise. Injection trends evidenced on the whole edifices or only on their emerged parts are represented by plain and dotted lines, respectively. On the former volcano, the main injection trends are two rift zones, a straight one oriented $\mathrm{N} 30^{\circ} \mathrm{E}$ and an arcuate one N110-N $160^{\circ} \mathrm{E}$, converging in the cirque of Salazie. A sill zone is also observed in the cirques of Cilaos and Salazie. These three injection trends localize brittle deformation in their vicinity, consisting in two perpendicular extensions near the rift zones and a compression near the sill zones. Red and yellow arrows represent the $\sigma_{3}$ axis of these two extensions, with a size symbolizing the dominant extensional direction. Green squares represent the vertical $\sigma_{3}$ axis of compression. At Piton de la Fournaise, the straight rift zone is NW-SE and the arcuate rift zone has two branches NE and SE. (For interpretation of the references to colour in this figure legend, the reader is referred to the web version of this article.) 
considered to have formed after 0.2 Ma (e.g. Kluska, 1997; Salvany et al., 2012). The plutonic complex was thus frozen by the time of deformation and rift zone activity, as well as during the formation of the cirques. There is thus no ground to attribute the volcano-tectonics of Piton des Neiges to the growth and ductile deformation of the plutonic complex underneath. The situation is similar at Piton de la Fournaise, where hypovolcanic rocks neither show evidence of significant intracristalline plastic deformation, at least from the limited knowledge provided by cumulative xenoliths (Welsch et al., 2013). This does not preclude the existence of ductile bodies within the two La Réunion volcanoes, but restricts their possible location to the submarine part of the edifices. In this perspective, it should be noted that at least two major structures, the $\mathrm{N} 30^{\circ} \mathrm{E}$ Etang-Salé rift zone of Piton des Neiges and the NW - SErift zone of Piton de la Fournaise, root from the base of the submarine edifices or deeper (Fig. 10). It is thus possible that the brittle behavior of the emerged volcanoes, interpreted from the perpendicularity of rift zones and stresses, might apply to the entire edifices.

\subsection{Role of crustal heterogeneities}

Our interpretation that La Réunion volcanoes behave as brittle edifices leads to question whether their substratum is undergoing any deformation. La Reunion is bordered by several crustal structures, including two transform faults $N 30^{\circ} \mathrm{E}$ and a paleo-ridge segment $N 120^{\circ} \mathrm{E}$. Michon et al. (2007) noticed the correlation between the orientation of these structures and the main structural trends at La Réunion and particularly at Piton de la Fournaise volcano. Our study tends to confirm that at Piton des Neiges, the rift zones and the deformation pattern are also aligned with the crustal structures. The crustal structures around La Réunion are associated with an old oceanic ridge, supposed to be inactive since $\sim 60 \mathrm{Ma}$ (Dyment, 1991). However, these structures border a bathymetric high, the Mascarene plateau, and a slight crustal doming is observed under La Réunion (Michon et al,, 2007). Lénat et al. (2009) proposed that the upward flow of the mantle plume, trapped by the tectonic lineaments caused the uplift of the Mascarene plateau by a process of dynamic support of the lithosphere. Michon et al. (2007) interpreted the crustal doming as an isostatic uplift due to thermal thinning of the lithosphere and magma underplating. Both studies suggest that these processes reactivated the preexisting tectonic structures around La Réunion. Of the deepest structures of La Réunion, at least one of them, the NW-SE rift zone of Piton de la Fournaise, is active down to the base of the oceanic crust according to seismicity (Michon et al., 2015). It is thus likely that the preexisting fabric of the oceanic crust acts as pathways for magma injections under La Réunion edifices, explaining the alignment of rift zones, and consequently of deformation structures, with the inherited crustal fabric. We therefore conclude this study by suggesting that it may be the fabric of the oceanic crust, and its rheology, that guides the asymmetric spreading of La Réunion volcanoes.

\section{Conclusion}

Our study of intrusion and deformation patterns provides a wider perspective of Piton des Neiges' volcano-tectonics. The intrusive system of this volcano is organized into three perpendicular zones of intrusion concentration, two 5-10 km wide rift zones and two $\sim 1 \mathrm{~km}$ thick sill zones. One of the rift zones runs straight to the south of the edifice in the direction $\mathrm{N} 30^{\circ} \mathrm{E}$, and was active during shield building and in the differentiated stage. The other rift zone, bowed from $\mathrm{N} 110^{\circ} \mathrm{E}$ to $\mathrm{N} 160^{\circ} \mathrm{E}$ toward the outer NE flank of the edifice, is inactive since at least the differentiated stage of the volcano. The two rift zones converge toward the cirque of Salazie, north of the present-day summit of Piton des Neiges. The sill zones occurring in the cirques of Cilaos and Salazie were active in the shield building stage as well as in the terminal differentiated stage.

The tectonics in the edifice is dominated by two perpendicular extensions, one in the direction NW-SE mostly occurring on the southern half of the edifice, the other one oriented NNE-SSW and mostly occurring on the northern half. Compression also occurs in the most internal parts of the edifice within the sill zones or in their vicinity. There is thus a spatial relationship and a mechanical compatibility between intrusion zones and deformation structures.

The occurrence of three perpendicular injection trends and perpendicular stress regimes supports the idea that the volcano-tectonics of Piton des Neiges proceeded by co-intrusive stress permutations, which implies a brittle edifice behavior rather than a ductile behavior. The pattern of intrusion trends and tectonics suggests that the spreading of Piton des Neiges is asymmetric rather than radial, which is also an indicator of brittle edifice rheology according to analogue modeling. The volcano-tectonics of Piton des Neiges appears to be comparable with that of Piton de la Fournaise, both volcanoes being made of perpendicular rift zones, one of which has a horse-shoe shape that delimits a sector collapse. We therefore suggest that La Réunion volcanoes are strong brittle edifices whose deformation is related to intrusive activity, rather than gravitationally spreading ductile volcanoes like Hawaii or Mount Etna.

\section{Acknowledgement}

Structural data were measured with the help of Elodie Brothelande, Carole Berthod, Céline Vidal, Pierre Belle, Gabriel Huot, Julia Eychenne, and Pierre-Emmanuel Bazet, who are thanked for their participation to the fieldwork. We thank A. Tibaldi and B. van Wyk de Vries for their thoughtful reviews that improved the quality of the manuscript. This research was funded by the University of La Réunion and by grants from INSU-CNRS ("Sill'nslip" and "Runrise" projects). This is IPGP contribution 3874 .

\section{References}

Acocella, V., Neri, M., 2009. Dike propagation in volcanic edifices: overview and possible developments. Tectonophysics 471 (1-2), 67-77.

Angelier, J., 1984. Analysis of fault slip data sets. J. Geophys. Res. 89 (B7), 5835-5848. Angelier, J., 1994. Fault slip analysis and paleostress reconstruction. In: Hancock, P.L. (Ed.), Continental deformation. Pergamon Press, Oxford, pp. 53-100.

Arnaud, N., 2005. Les processus de démantèlement des volcans, la cas d'un volcan bouclier en milieu océanique: le Piton des Neiges (Ile de la Réunion). Université de la Réunion, (Unpubl.) PhD Thesis, pp. 422.

Bachèlery, P., Robineau, B., Courteaud, M., Savin, C., 2003. Avalanches de débris sur le flanc occidental du volcan-bouclier Piton des Neiges (Réunion). Bulletin de la Société géologique de France 174 (2), 125-140.

Bernard, A., Munschy, M., 2000. Le bassin des Mascareignes et le bassin de Laxmi (Océan Indien occidental) se sont-ils formés à l'axe d'un même centre d'expansion? C.R. Acad. Sci. Paris 330, 777-783.

Berthod, C., 2016. Relations entre systèmes intrusifs et instabilités sur un. volcan basaltique (Piton des Neiges, La Réunion). (Unpubl.) PhD Thesis, Université de la Réunion. (273 pp.).

Berthod, C., Famin, V., Bascou, J., Michon, L., Ildefonse, B., Monié, P., 2016. Evidence of sheared sills related to flank destabilization in a basaltic volcano. Tectonophysics 674, 195-209.

Borgia, A., Delaney, P.T., Denlinger, R.P., 2000. Spreading volcanoes. Annu. Rev. Earth Planet. Sci. 28, 539-570.

Bret, L., Fèvre, Y., Join, J.-L., Robineau, B., Bachèlery, P., 2003. Deposits related to degradation processes on Piton des Neiges Volcano (Reunion Island): overview and geological hazard. J. Volcanol. Geotherm. Res. 123 (1-2), 25-41.

Byrne, P.K., Holohan, E.P., Kervyn, M., van Wyk de Vries, B., Troll, V.R., Murray, J.B., 2013. A sagging-spreading continuum of large volcano structure. Geology 41 (3), 339-342.

Casagli, N., Tibaldi, A., Merri, A., Del Ventisette, C., Apuani, T., Guerri, L., FortunyGuasch, J., Tarchi, D., 2009. Deformation of Stromboli Volcano (Italy) during the 2007 eruption revealed by radar interferometry, numerical modelling and structural geological field data. J. Volcanol. Geotherm. Res. 182 (3), 182-200.

Cayol, V., Catry, T., Michon, L., Chaput, M., Famin, V., Bodart, O., Froger, J.L., Romagnoli, C., 2014. Sheared sheet intrusions as a mechanism for lateral flank displacement on basaltic volcanoes: applications to Réunion Island volcanoes. J. Geophys. Res. Solid Earth 119, 7607-7635.

Chaput, M., Famin, V., Michon, L., 2014a. Deformation of basaltic shield volcanoes under cointrusive stress permutations. J. Geophys. Res. Solid Earth 119 (1), 274-301.

Chaput, M., Pinel, V., Famin, V., Michon, L., Froger, J.L., 2014b. Cointrusive shear displacement by sill intrusion in a detachment: a numerical approach. Geophys. Res. Lett. 41, 1937-1943. 
Chaput, M., Famin, V., Michon, L, 2017. "Intrusion data and deformation structures at Piton des Neiges volcano (La Réunion Island)", Mendeley Data, v1. http://dx.doi.org/ 10.17632/4w7mhmm2ry.1.

Chevallier, L., 1979. Structures et évolution du volcan Piton des Neiges, Ile de La Réunion - Leurs relations avec les structures du bassin des Mascareignes, Océan Indien occidental., (Unpubl.) PhD Thesis. Université Scientifique et Médicale, Grenoble (187 pp).

Chevallier, L., Vatin-Perignon, N., 1982. Volcano-structural evolution of Piton des Neiges, Reunion Island, Indian Ocean. Bull. Volcanol. 45 (4), 285-298.

Clarke, D., Brenguier, F., Froger, J.L., Shapiro, N.M., Peltier, A., Staudacher, T., 2013. Timing of large volcanic flank movement at Piton de la Fournaise Volcano using noise-based seismic monitoring and ground deformation measurements. Geophys. J. Int. 195 (2), 1132-1140.

Delcamp, A., Van Wyk de Vries, B., James, M.R., 2008. The influence of edifice slope and substrata on volcano spreading. J. Volcanol. Geotherm. Res. 177 (4), 925-943.

Delcamp, A., Van Wyk de Vries, B., James, M.R., Gailler, L.S., Lebas, E., 2012. Relationships between volcano gravitational spreading and magma intrusion. Bull. Volcanol. 74, 743-765.

Delvaux, D., Sperner, B., 2003. New aspect of tectonic stress inversion with reference to the TENSOR program. In: Nieuwland, D.A. (Ed.), New Insights into Structural Interpretation and Modelling. Geological Society, Special Publications, London, pp. 75-100.

Deniel, C., Kieffer, G., Lecointre, J., 1992. New 230Th-238U and 14C age determinations from Piton des Neiges volcano, Reunion - a revised chronology for the differentiated series. J. Volcanol. Geotherm. Res. 51 (3), 253-267.

Dyment, J., 1991. Structure et évolution de la lithosphère océanique dans l'Océan Indien: apport des anomalies magnétiques, (Unpubl.) PhD Thesis. Université Louis Pasteur, Strasbourg (374 pp).

Famin, V., Michon, L., 2010. Volcano destabilization by magma injections in a detachment. Geology 38 (3), 219-222.

Famin, V., Berthod, C., Michon, L., Eychenne, J., Brothelande, E., Mahabot, M.M., Chaput, M., 2016. Localization of magma injections, hydrothermal alteration, and deformation in a volcanic detachment (Piton des Neiges, La Réunion). J. Geodyn. 101, 155-169.

Fretzdorff, S., Stoffers, P., Devey, C.W., Munschy, M., 1998. Structure and morphology of submarine volcanism in the hotspot region around Réunion Island, western Indian Ocean. Mar. Geol. 148 (1-2), 39-53.

Froger, J.L., Famin, V., Cayol, V., Augier, A., Michon, L., Lénat, J.F., 2015. Time-dependent displacements during and after the April 2007 eruption of Piton de la Fournaise, revealed by interferometric data. J. Volcanol. Geotherm. Res. 296, 55-68.

Gailler, L.-S., Lénat, J.-F., 2012. Internal architecture of La Réunion (Indian Ocean) inferred from geophysical data. J. Volcanol. Geotherm. Res. 221-222, 83-98.

Geoffroy, L., Bergerat, F., Angelier, J., 1993. Modification d'un champ de contrainte re gional par un champ de contraintesmagmatiques local; Exemple de l'ile de Skye (Ecosse) au Paleocene. Bulletin de la Société Geologique de France. 164 (4), 541-552.

Gillot, P.Y., Nativel, P., 1982. K-Ar chronology of the ultimate activity of Piton des Neiges volcano, Reunion Island, Indian ocean. J. Volcanol. Geotherm. Res. 13 (1-2), 131-146.

Gillot, P., Nativel, P., Condomines, M., 1990. Evolution volcano-structurale du Piton de la Fournaise, depuis $0.53 \mathrm{Ma}$, Le Volcanisme de la Réunion Monographie Centre de Recherches Volcanologiques, Clermont-Ferrand. pp. 243-256.

Got, J.-L., Peltier, A., Staudacher, T., Kowalski, P., Boissier, P., 2013. Edifice strength and magma transfer modulation at Piton de la Fournaise volcano. J. Geophys. Res. Solid Earth 118 (9), 5040-5057.

Gudmundsson, A., 2006. How local stresses control magma-chamber ruptures, dyke injections, and eruptions in composite volcanoes. Earth Sci. Rev. 79 (1-2), 1-31.

Haurie, J.L., 1987. Géodynamique des cirques de la Réunion : implications géotechniques et stabilité des versants. (Unpubl.) PhD Thesis. Université Scientifique et Médicale de Grenoble, Grenoble (284 pp).

Kluska, J.-M., 1997. Evolution magmatique et morpho-structurale du Piton des Neiges au cours des derniers 500000 ans. Unpubl.) PhD Thesis, Université Paris Sud, pp. 93.

Kühn, D., Dahm, T., 2008. Numerical modelling of dyke interaction and its influence on oceanic crust formation. Tectonophysics 447 (1), 53-65.

Labazuy, P., 1996. Recurrent landslides events on the submarine flank of Piton de la Fournaise volcano (Reunion Island). Geol. Soc. Lond., Spec. Publ. 110 (1), 295-306.

Lacombe, O., 2012. Do fault slip data inversions actually yield "paleostresses" that can be compared with contemporary stresses? A critical discussion. C.R. Geosci. 344, 159-173.
Lacquement, F., Nehlig, P., 2008. Notice des cartes géologiques des cirques du Piton des Neiges (Ile de La Réunion, France) - Rapport final BRGM/RP56730FR.

Le Friant, A., Lebas, E., Clément, V., Boudon, G., Deplus, C., de Voogd, B., Bachèlery, P., 2011. A new model for the evolution of La Réunion volcanic complex from complete marine geophysical surveys. Geophys. Res. Lett. 38 (9). http://dx.doi.org/10.1029/ 2011 GL047489.

Lehto, H.L., Roman, D.C., Moran, S.C., 2010. Temporal changes in stress preceding the 2004-2008 eruption of Mount St. Helens, Washington. J. Volcanol. Geotherm. Res. $198(1-2), 129-142$.

Lénat, J.-F., Labazuy, P., 1990. Morphologies et structures sous-marines de la Réunion. In: Lénat, J.-F. (Ed.), Le volcanisme de la Réunion - Monographie, pp. 43-74.

Lénat, J.-F., Merle, O., Lespagnol, L., 2009. La Réunion: an example of channeled hot spot plume. J. Volcanol, Geotherm. Res. 184 (1-2), 1-13.

Lund, B., Townend, J., 2007. Calculating horizontal stress orientations with full or partial knowledge of the tectonic stress tensor. Geophys. J. Int. 170 (3), 1328-1335.

Maillot, E, 1999. Les systèmes intrusifs des volcans boucliers océaniques: Ile de la Réunion (Océan Indien). Approche structurale et expérimentale. (Unpubl.) PhD Thesis. Université de la Réunion (289 pp).

McDougall, I., 1971. The geochronology and evolution of the young volcanic island of Réunion, Indian Ocean. Geochim. Cosmochim. Acta 85, 261-288.

Michon, L., Saint-Ange, F., Bachelery, P., Villeneuve, N., Staudacher, T., 2007. Role of the structural inheritance of the oceanic lithosphere in the magmato-tectonic evolution of Piton de la Fournaise volcano (La Réunion Island). J. Geophys. Res. 112 (B04205), $1-21$.

Michon, L., Ferrazzini, V., Di Muro, A., Villeneuve, N., Famin, V., 2015. Rift zones and magma plumbing system of Piton de la Fournaise volcano: how do they differ from Hawaii and Etna? J. Volcanol. Geotherm. Res. 303, 112-129.

Nehlig, P., Quinquis, P., Bucelle, M., Odon, O., 2006. Carte géologique de La Réunion, échelle 1/100000e. En collaboration avec P. Bachèlery, P. Mairine, N. Arnaud, T. Boyer, J.L. Hoareau, J.L. Join, H. Nassor, B. Robineau, S. Techer, N. Villeneuve, B. Welsch, G. Billard, L. Bret et Y. Fèvre. Editions BRGM.

Oehler, J.-F., Labazuy, P., Lénat, J.-F., 2004. Recurrence of major flank landslides during the last 2-Ma-history of Reunion Island. Bull. Volcanol. 66 (7), 585-598.

Oehler, J.F., van Wyk de Vries, B., Labazuy, P., 2005. Landslides and spreading of oceanic hot-spot and arc shield volcanoes on Low Strength Layers (LSLs): an analogue modeling approach. J. Volcanol. Geotherm. Res. 144 (1-4 SPEC. ISS), 169-189.

Oehler, J.F., Lénat, J.F., Labazuy, P., 2008. Growth and collapse of the Reunion Island volcanoes. Bull. Volcanol. 70 (6), 717-742.

Quidelleur, X., Holt, J.W., Salvany, T., Bouquerel, H., 2010. New K-Ar ages from La Montagne massif, Réunion Island (Indian Ocean), supporting two geomagnetic events in the time period 2.2-2.0 Ma. Geophys. J. Int. 182 (2), 699-710.

Salvany, T., 2009. Evolution morphostructurale de volcans boucliers intraplaques océaniques: Exemple des volcans de l'île de la Réunion (Océan Indien). (Unpubl.) PhD Thesis. Université Paris Sud (384 pp).

Salvany, T., Lahitte, P., Nativel, P., Gillot, P.-Y., 2012. Geomorphic evolution of the Piton des Neiges volcano (Réunion Island, Indian Ocean): competition between volcanic construction and erosion since 1.4 Ma. Geomorphology 136 (1), 132-147.

Smietana, M., 2011. Petrologie, geochronologie (K, Ar) et géochimie élémentaire et isotopique ( $\mathrm{Sr}, \mathrm{Nd}, \mathrm{Hf}, \mathrm{Pb}$ ) de laves anciennes de La Réunion: Implications sur la construction de l'édifice volcanique. Université de la Réunion, (Unpubl.) $\mathrm{PhD}$ Thesis (238 pp).

Sperner, B., Müller, B., Heidbach, O., Delvaux, D., Reinecker, J., Fuchs, K., 2003. N. D.A. (Editor), New Insights into Structural Interpretation and Modelling. Tectonic stress in the Earth's crust: advances in the World Stress Map project. Geological Society, Special Publications, London, pp. 101-116.

Tibaldi, A., 2015. Structure of volcano plumbing systems: a review of multi-parametric effects. J. Volcanol. Geotherm. Res. 298, 85-135.

Tibaldi, A., Bonali, F.L., 2017. Intra-arc and back-arc volcano-tectonics: magma pathways at Holocene Alaska-Aleutian volcanoes. Earth Sci. Rev, 167, 1-26.

Tridon, M., Cayol, V., Froger, J.L., Augier, A., Bachèlery, P., 2016. Inversion of coeval shear and normal stress of Piton de la Fournaise flank displacement. J. Geophys. Res. Solid Earth 121 (11), 7846-7866.

Vigneresse, J.L., Tikoff, B., Améglio, L., 1999. Modification of the regional stress field by magma intrusion and formation of tabular granitic plutons. Tectonophysics 302 (3), 203-224.

Welsch, B., Faure, F., Famin, F., Baronnet, A., Bachèlery, P., 2013. Dendritic crystallization: a single process for all textures of olivine in basalts? J. Petrol. 54 (3), 539-574. 